\title{
ON MOSS FAMILY LEMBOPHYLLACEAE IN THE RUSSIAN FAR EAST
} \section{О МХАХ СЕМЕЙСТВА LЕМВОРНҮLLAСЕАЕ НА РОССИЙСКОМ ДАЛЬНЕМ ВОСТОКЕ}

\author{
Elena A. IGNATOVA ${ }^{1}$, Vladimir E. Fedosov ${ }^{1,2}$, Alina V. FedOROVA ${ }^{3}$, UlyanA N. SPIRINA ${ }^{3,4}$ \\ $\&$ MICHAEL S. IGNATOV ${ }^{1,3}$ \\ ЕЛЕНА А. ИГНАТОВА ${ }^{1}$, ВЛАДИМИР Е. ФЕДОСОВ ${ }^{1,2}$, АЛИНА В. ФЕДОРОВА $^{3}$, УЛЬЯНА Н. СПИРИНА
МИХАИЛ С. ИГНАТОВ
}

\begin{abstract}
An integrateive approach to the revision of the Lembophyllaceae in the Russian Far East, includinig molecular phylogenetic and morphological studies, revealed five species, three of Dolichomitriopsis, including one new species, Dolichomitriopsis cherdantseviae, and one species of Dolichomitra, one new genus Dolichomitriadelphus for the taxon commonly known as Isothecium hakkodense. The species known as Isothecium subdiversiforme is still not found in Russia, so it was analyzed based on Japanese material and also determined to be unrelated to any other species of Lembophyllaceae, thus it is segregated in a genus of its own, Isotheciastrum. The combined analysis of European, Asian and American species shows that the genus Isothecium has mostly Amphiatlantic distribution and combines species of I. alopecuroides affinity. The group of Isothecium myosuroides and related species form a clade sister to Asian Dolichomitra, Dolichomitriopsis, Isotheciastrum, and American Bryolawtonia and Tripterocladium. This fact suggests a resurrection of the genus Pseudisothecium Grout for I. myosuroides, I. stoloniferum, I. interludens, I. prolixum, I. montanum, I. holtii, I. cardotii, and I. cristatum. All species of the family from the Russian Far East are illustrated and the variation of their morphology is discussed.
\end{abstract}

Резюме

Интегративный подход к ревизии гербарных образцов Lembophyllaceae c российского Дальнего Востока, включающий молекулярно-филогенетический анализ и сравнение морфологических приззнаков, позволил выявить в регионе пять видов, три из которых относятся к родуDolichomitriopsis, один из них новый для науки, Dolichomitriopsis cherdantseviae, а также один вид из рода Dolichomitra и один вид из нового рода Dolichomitriadelphus, ранее известный как Isothecium hakkodense. Isothecium subdiversiforme, пока не найденный в России, был также включен в анализ с использованием образцов из Японии; он оказался не родственным ни одному из известных видов Lembophyllaceae, и на этом основании он выделен в особый род Isotheciastrum. Комбинированный анализ европейских, азиатских и американских видов показал, что род Isothecium имеет б.ч. амфиатлантическое распространение и объединяет виды из родства I. alopecuroides. Isothecium myosuroides и родственные ему виды образуют кладу, сестринскую азиатским видам из родов Dolichomitra, Dolichomitriopsis, Isotheciastrum, а также американским видам из родов Bryolawtonia и Tripterocladium. Это предполагает восстановление рода Pseudisothecium Grout для I. myosuroides, I. stoloniferum, I. interludens, I. prolixum, I. montanum, I. holtii, I. cardotii и I. cristatum. Приводятся иллюстрации для всех российских дальневосточных видов семейства и обсуждается вариабельность их морфологических признаков.

KEYWORDS: bryophytes, molecular phylogeny, taxonomy, branch primordia, Isotheciastrum, Dolichomitriadelphus, Dolichomitra, Dolichomitriopsis, Pseudisothecium

\section{INTRODUCTION}

Recent check-list of the moss flora of Russia (Ignatov et al., 2006) and of Far Eastern mosses (Cherdantseva et al., 2018) mentioned only two species of the Lembophyllaceae in the Russian Far East: Dolichomitriopsis diversiformis (Mitt.) Nog. and Isothecium hakkodense Besch.
Even despite of only two, these species were not always correctly identified in herbaria. The difficulties in identification were caused by broad variation, absence of characters which are easy to present in manuals, and due to placement these two species into different genera, moreover, classified in different families and published in the

\footnotetext{
1 - Lomonosov Moscow State University, Faculty of Biology, Plant Ecology and Geography Dept., Leninskie Gory Str. 1-12, Moscow 119234 Russia; e-mails: arctoa@list.ru; fedosov v@mail.ru

2 - Botanical Garden-Institute, FEB RAS, Makovskogo Street, 142, Vladivostok, 690024, Russia

3 - Tsitsin Main Botanical Garden, Russian Academy of Sciences, Botanicheskaya Str., 4, Moscow 127276 Russia; e-mails: alina77777@mail.ru; misha ignatov@list.ru

4 - Faculty of Biology, Tver State University, Zhelyabova 33, Tver 170100 Russia; e-mail: ulayspirina@mail.ru
} 
"Illustrated moss flora of Japan" in different volumes (Noguchi \& Iwatsuki, 1989; Noguchi et al., 1991).

The species of Isothecium are widespread in Europe and Macaronesia, and two most common European species, I. alopecuroides (Lam. ex Dubois) Isov. and I. myosuroides Brid., extend to the western regions of European Russia, whereas species of Isothecium are absent in the territories east of the Caucasus and up to the Russian Far East, where I. hakkodense occurs. The original intension of this study was to check if the generic position of the latter species can be confirmed using a molecular phylogenetic approach.

However, it soon became clear that the East Asian Lembophyllaceae comprise a more puzzling complex, thus more groups of this family were involved in the study.

The circumscription of the family Lembophyllaceae is vague. It originally included four genera: Camptochaete, Dolichomitra, Isothecium, and Lembophyllum (Brotherus, 1907). The subsequent challenges in the scope of the family were overviewed by Tangney (1997), who accepted in it Camptochaete, Fallaciella, Fifea, Lembophyllum and Weymouthia, moving ten genera to other families. For example, Isothecium was placed in Brachytheciaceae and Dolichomitriopsis in Meteoriaceae.

The same circumscription of the family was accepted by Quandt et al. (2000), who considered it as a sister clade to Meteoriaceae; further Quandt et al. (2009) expanded it based on molecular phylogenetic reconstruction and included in the family a suite of lineages sister to the Lembophyllaceae sensu Tangney (1997). Their paper provides a historical overview of the Lembophyllaceae circumscription. Classification by Frey \& Stech (2009) mostly follows Quandt et al. (2009); 14 genera are accepted in the Lembophyllaceae: Bestia, Camptochaete, Dolichomitra, Dolichomitriopsis, Fallaciella, Fifea, Isothecium, Lembophyllum, Looseria, Neobarbella, Pilotrichella, Rigodium, Tripterocladium, and Weymouthia. Goffinet et al. (2009) also included in the Lembophyllaceae the genera Acrocladium and Orthostichella, but did not include Dolichomitra, Rigodium and Tripterocladium. Since then, Nogopterium (=Pterogonium) appeared in some molecular phylogenetic analyses within the Lembophyllaceae (Troitsky et al., 2008) or sister to that family (Huttunen et al., 2012; Ignatov et al., 2019) and thus it was placed in this family along with Mawenzhangia, newly described from Yunnan (Enroth et al., 2018). Orthostichella was placed in a separate family (Enroth et al., 2019). Finally, Ignatov et al. (2019) based on the molecular phylogenetic reconstruction of the Neckeraceae-Orthostichellaceae-Lembophyllaceae phylogeny suggested the inclusion of Heterocladium s.str. in the Lembophyllaceae. However, differences in the obtained topologies occurred from study to study, partly due to the differences in representation of the genera and partly due to different studied markers.

Isothecium was the only genus in focus of special molecular studies and therefore it was extensively sampled
(Draper et al., 2007, 2015), but mostly European species were involved in these studies and thus affinities of Asian representatives of the genus were not comprehensively addressed until now. The aim of the present study was to consider Asian species of Isothecium and closely related genera in the broader molecular phylogenetic context and to estimate their affinities based on the obtained reconstructions.

\section{MATERIAL AND METHODS}

\section{Molecular phylogenetic studies}

The material used in the present study was sampled from MW and MHA and supplemented by sequences available in GenBank. For the molecular-phylogenetic study we used five markers, nuclear ITS1,2 and 5.8 rRNA gene, plastid $t r n \mathrm{G}$ intron and $t r n \mathrm{~S}-\mathrm{F}$ region, which were successfully used in phylogenetic studies of Lembophyllaceae and related families (Vanderpoorten et al., 2002; Draper et al., 2007, 2015; Olsson et al., 2009; Quandt at al., 2009; Hodgetts \& Vanderpoorten, 2018, etc.). Besides the representatives of Lembophyllaceae from temperate areas of Asia, the closely related lineages of Isothecium were originally sampled for phylogenetic study. In total, 19 ingroup specimens were studied de novo. The obtained alignments were added by ITS, $\operatorname{trn} \mathrm{G}$ and $t r n \mathrm{~L}-\mathrm{F}$ sequences of Isothecium from GenBank, obtained by Draper et al. $(2007,2015)$, and by ITS \& trnL$\mathrm{F}$ (in some cases $\operatorname{trn} \mathrm{T}-\operatorname{trn} \mathrm{F}$ or $\operatorname{trn} \mathrm{S}-\operatorname{trn} \mathrm{F}$ ) sequences of miscellaneous lineages of Lembophyllaceae obtained by Quandt et al. (2000, 2009) and Olsson et al. (2009). To provide representation of major clades of pleurocarpous mosses, both closely related groups and putative outgroups, sequences for suite of species well represented in GenBank were included based on the previously published reconstructions and our alignment designed for phylogenetic study of Anomodon and Heterocladium (Ignatov et al., 2019). Vouchers of the newly studied specimens and GenBank accession numbers of all used sequences are compiled in Appendix 1.

The laboratory protocol was essentially the same as in previous moss studies, described in detail by, e.g., Gardiner et al. (2005) and Hedenäs (2017). Sequences were aligned using MAFFT v. 7.402 (Katoh \& Standley, 2013) with standard settings and then edited manually in BioEdit (Hall, 1999). At first, ITS (124 terminals, 792 bp), $\operatorname{trn} \mathrm{G}$ (94 terminals, $616 \mathrm{bp}$ ), trnL-F (134 terminals, $431 \mathrm{bp}$ ) and trnS-F + trnL-F (56 terminals, $1938 \mathrm{bp}$ ), were analyzed separately to check their congruence. Since no supported conflict of topologies were observed among the trees inferred from these markers, the combined ITS - $\operatorname{trn} \mathrm{G}$ - trnS-F, (including trnL-F) dataset (83 terminals, $3346 \mathrm{bp}$ ), divided into two partitions, for nr and cp data, was analyzed. In all analyses indels were coded using simple indel coding approach (Simmons \& Ochoterena, 2000) in SeqState 1.4.1 (Müller, 2005). An inversion in the $\operatorname{trn} \mathrm{L}-t r n \mathrm{~F}$ spacer was coded by binary code. 


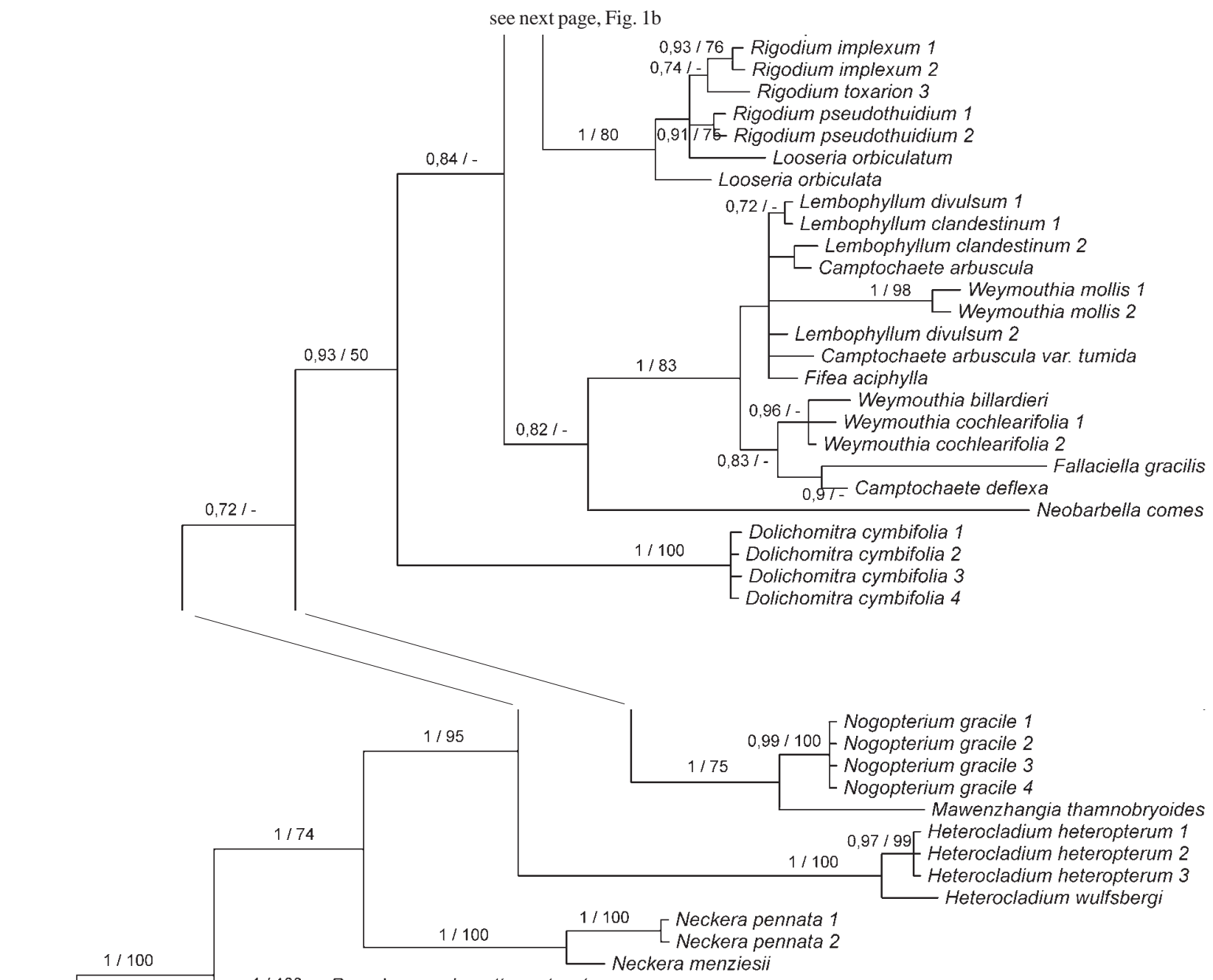

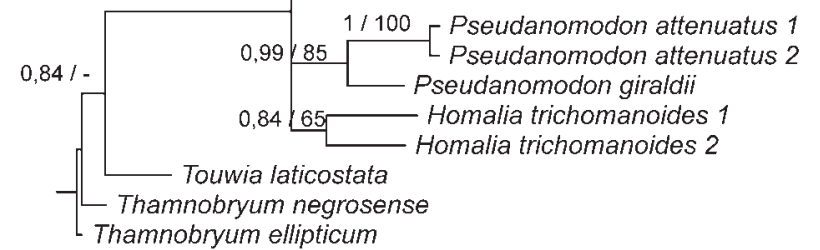

Thamnobryum ellipticum
Fig. 1a. Basal part of the Bayesian molecular phylogenetic reconstruction based on nuclear ITS data. Bayesian posterior probability and bootstrap support from maximum likelyhood analysis are shown at branches. Terminal part of the tree see in the next page, Fig. 1b. GenBank accession numbers and oucher specimen information see in Appendix 1.
Bayesian Analyses were performed by running two parallel analyses in MrBayes 3.2.7a (Ronquist et al., 2012). For the single gene sets analyses each run consisted of six Markov chains, 10000000 generations with default number of swaps and sampling frequency one tree each 2500 generations. For the combined dataset the analysis consisted of eight Markov chains and 25000000 generations, with the default number of swaps and sampling frequency one tree each 5000 generations was performed. The chain temperature was set at 0.02 in all analyses. Convergence of each analysis was evaluated using Tracer1.4.1 (Rambaut \& Drummond, 2007). Consensus trees were calculated after omitting the first $25 \%$ trees as burn-in. Maximum Likelihood (ML) trees were estimated using RaxML 8.2.12 (Stamatakis, 2014) from 1000 independent searches each starting from distinct random trees. Robustness of the nodes was assessed using standard non-parametric bootstrap with 1000 itera- tions. Analyses were performed on the Cipres Science Gateway (http://www.phylo.org/portal2) on XSEDE (Miller et al., 2010). The default outgroup for rooting the trees was evaluated using the previously published reconstructions of the backbone phylogeny of pleurocarpous mosses (Huttunen et al., 2012).

Morphological studies were conducted by a standard method, with additional attention to the structure of branch primordia, and especially proximal branch leaves. Previous studies of Spirina \& Ignatov (2015) found them to have diverse and unusual structure, thus we studied them with the goal to find additional characters, important as morphological distinctions between genera that are not contrasting enough in the Lembophyllaceae. For SEM study we took several branches of one specimen selected as "typical" for the species after ordinary observation under light microscope. Chosen herbarium samples were soaked in wa- 


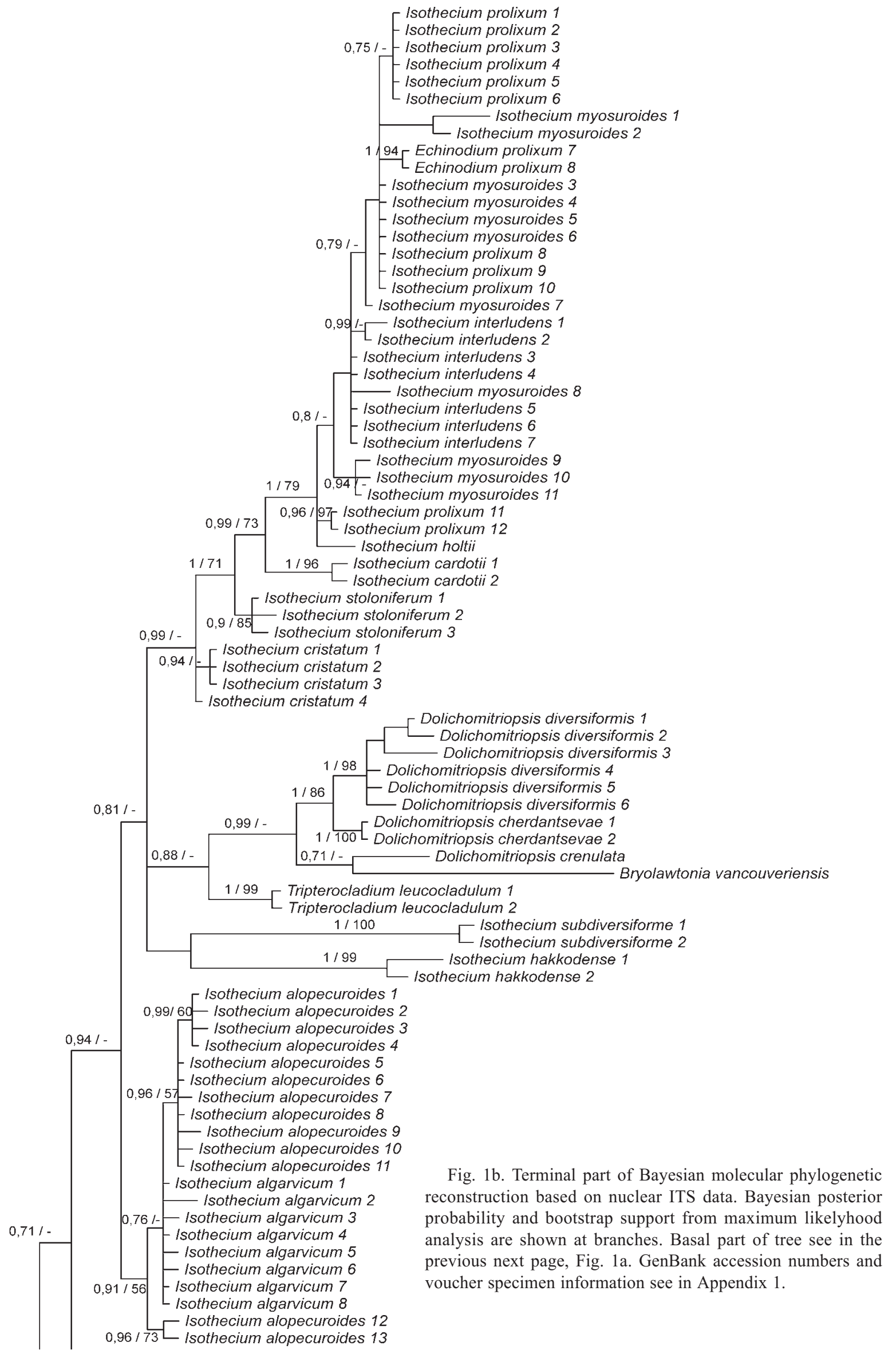




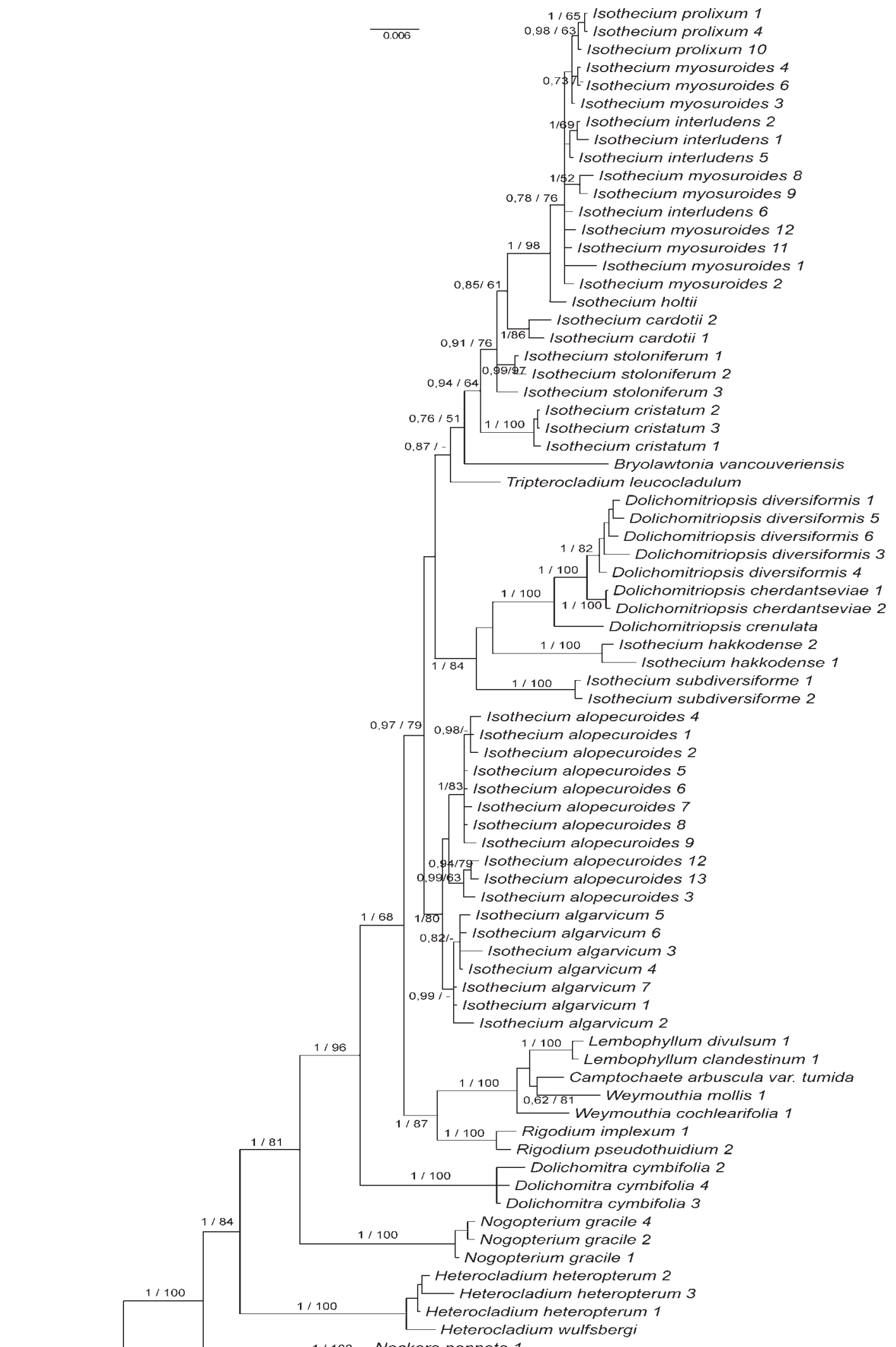

$1 / 100$ $1 / 100 \quad 1 / 100+\begin{aligned} & \text { Neckera pennata 1 } \\ & \text { Neckera pennata 2 }\end{aligned}$ Neckera menziesii $0.86 /-$ Pseudanomodon giraldi Pseudanomodon attenuatus 1 1/100 Homalia trichomanoides 1

Thamnobryum negrosense

$1 / 99$ Touwia laticostata Thamnobryum ellipticum
Fig. 2. Bayesian molecular phylogenetic reconstruction based on concatenated nuclear ITS and chloroplastic ITS-trnG-trnS-F (including $\operatorname{trn} \mathrm{L}-\mathrm{F}$ ) data. Bayesian posterior probability and bootstrap support from maximum likelyhood analysis are shown at branches. GenBank accession numbers and voucher specimen information see in Appendix 2. 
ter for 24 hours, then fixed in 2,5\% glutaraldehyde for 24 hours, post-fixed with $1 \%$ osmium tetroxide, water solution, for 3 hours. Then material was dehydrated through a graded ethanol/acetone series to $100 \%$ acetone and dried at a critical point, covered by gold and observed under SEM Jeol 6380. Partly previously done SEM images are used here: they were obtained under a similar preparation, under SEM LEO-430.

\section{RESULTS}

\section{Molecular phylogeny.}

Lembopyllaceae s.l., including Heterocladium and Nogopterium +Mawenzhangia were resolved as monophyletic, originating from the Neckeraceae s.l. ancestral groups. The difference between ITS and ITS $+t r n \mathrm{~S}-$ $\mathrm{F}+$ trn $\mathrm{G}$ analyses refer to the support values for two basal lineages, Heterocladium and Nogopterium + Mawenzhangia. The high statistical support in the ITS tree was found only for Lembophyllaceae s.1. $(\mathrm{PP}=1, \mathrm{ML}=96)$, while the clade without these three genera, Lembophyllaceae s. str., has low support $(\mathrm{PP}=0.93, \mathrm{ML}=50)$. The concatenated tree has higher support for Lembophyllaceae s. str. $(\mathrm{PP}=1$, $\mathrm{ML}=96)$ than for Lembophyllaceae s.1. ( $\mathrm{PP}=1, \mathrm{ML}=84)$.

The most basal lineage in the Lembophyllaceae s. str. is the East Asian monospecific genus Dolichomitra. Next in the grade are mostly South Hemispheran clades of Rigodium and "core Lembophyllaceae" (in ITS tree, Fig. 1 ); which are combined in one clade in the concatenated tree (Fig. 2), and terminal clade is composed of Isotheci$u m$ and related taxa, most of them were earlier treated in the genus Isothecium. The genera of intermediate clade, Camptochaete, Fallaciella, Fifea, Lembophyllum, Looseria, Neobarbella, Rigodium, and Weymouthia are included in the present analysis to be certain that the species of the Far Eastern Lembophyllaceae do not relate to any of them; this is obvious from the topology in Figs. 1 and 2 , therefore, we do not address this group in detail.

The terminal, "Isothecium s.l."-clade, is low supported in ITS tree ( $\mathrm{PP}=0.94$ / $\mathrm{BS}<50)$, and only a little more in concatenated tree $(\mathrm{PP}=0.97 / \mathrm{BS}=79)$. The tree inferred from the analysis of combined dataset revealed in "Isothecium s.l."-clade three subclades, where clade (1) Isothecium alopecuroides + I. algarvicum W.E. Nicholson \& Dixon, with $\mathrm{PP}=1, \mathrm{BS}=80$, is sister to the join clade of other taxa, though the latter has very short branch and no support $(\mathrm{PP}<70, \mathrm{BS}<50)$. This join clade is formed of two subclades: (2) “East Asian" clade $(\mathrm{PP}=1, \mathrm{BS}=84)$, including species of the East Asian genus Dolichomitriopsis and two East Asian species treated as Isothecium, I. hakkodense and I. subdiversiforme Broth., and (3) the clade of species around Isothecium myosuroides. The latter includes several North American species, I. stoloniferum Brid., I. cardotii Kindb., and I. holtii Kindb., Macaronesian I. prolixum (Mitt.) M. Stech, Sim-Sim, Tangney \& D. Quand and West European I. interludens Stirt. and also two North American genera from Pacific North-West, Bryolawtonia and Tripterocladium.
In ITS tree Bryolawtonia and Tripterocladium occur in a different position, clustering with East Asian species as follows. The East Asian group is not resolved as a clade, but as two clades in tritomy, where the third is the clade of species around Isothecium myosuroides. One of clades (without support) includes two highly supported clades of two specimens of Isothecium hakkodense and of two specimens of Isothecium subdiversiforme. The second clade has a low support as a whole $(\mathrm{PP}=0.88$, $<50$ ), it includes a clade of two specimens of Tripterocladium $(\mathrm{PP}=1, \mathrm{ML}=99)$, which is sister to moderately supported clade of Dolichomitriopsis + Bryolawtonia $(\mathrm{P}=0.99, \mathrm{ML}<50)$. In the latter Bryolawtonia forms the almost unsupported clade with Dolichomitriopsis crenulata $\mathrm{S}$. Okamura $(\mathrm{P}=0.71, \mathrm{ML}<50)$, sister to the rest of Dolichomitriopsis $(\mathrm{P}=1, \mathrm{ML}=86)$, composed of two clades, one of six specimens of $D$. diversiformis $(\mathrm{PP}=1$, $\mathrm{ML}=98)$ and of two specimens of a new species described below $(\mathrm{PP}=1, \mathrm{ML}=100)$.

\section{Observation on branch primordia morphology}

The SEM pictures in Figs. 3-5 show polymorphism seen even within one sample, providing difficulties in their descriptions. Below we describe proximal branch leaves and branch primordia structures following terminology explained in detail in Spirina \& Ignatov (2015).

In Dolichomitra, Figs. 3A-C, the first and second proximal branch leaves are compound, with their parts sometimes spaced, short triangular to oblate or just in a shape of low ridge, entire to serrate and incised. The third or sometimes also fourth and fifth proximal branch leaves are shallowly bilobed. Overall branch primordium shape is low hemispheric, with rather remote position of outer elements.

In Lembophyllum, Figs. 3D-F, the first proximal branch leaf is steadily reduced but the second one is developed, it is entire or slightly dissected, while the third one is divided into 2 or 3 lobes almost to the base. Leaves are obtuse and overall shape of branch primordium is about compact hemispheric.

In Camptochaete, Figs. 3G-I, the first or the first and second proximal branch leaves are reduced. If the second leaf is present it is either dissected into 2-4 lobes or entire. The third leaf often is bilobed or rarely entire. Overall branch primordium shape is low hemispheric.

Rigodium brachypodium (Müll. Hal.) Paris, Figs. 3J$\mathrm{L}$, has constant reduction of the first leaf and occasional presence of the compound second one, with closely arranged 3-5 triangle segments, often without apparent connection to each other at the level of stem surface. The third leaf is hood-like, entire or bilobed and dissected almost to the base and sometimes even compound. Branch primordium is low hemispheric, moderately compact.

In Isothecium subdiversiforme, Figs. 3M-O, the proximal branch leaves at early stage are oblate, widely rounded and clearly bilobed, with the first proximal branch leaf occasionally reduced. More developed proximal branch leaves are distally truncate and serrulate 

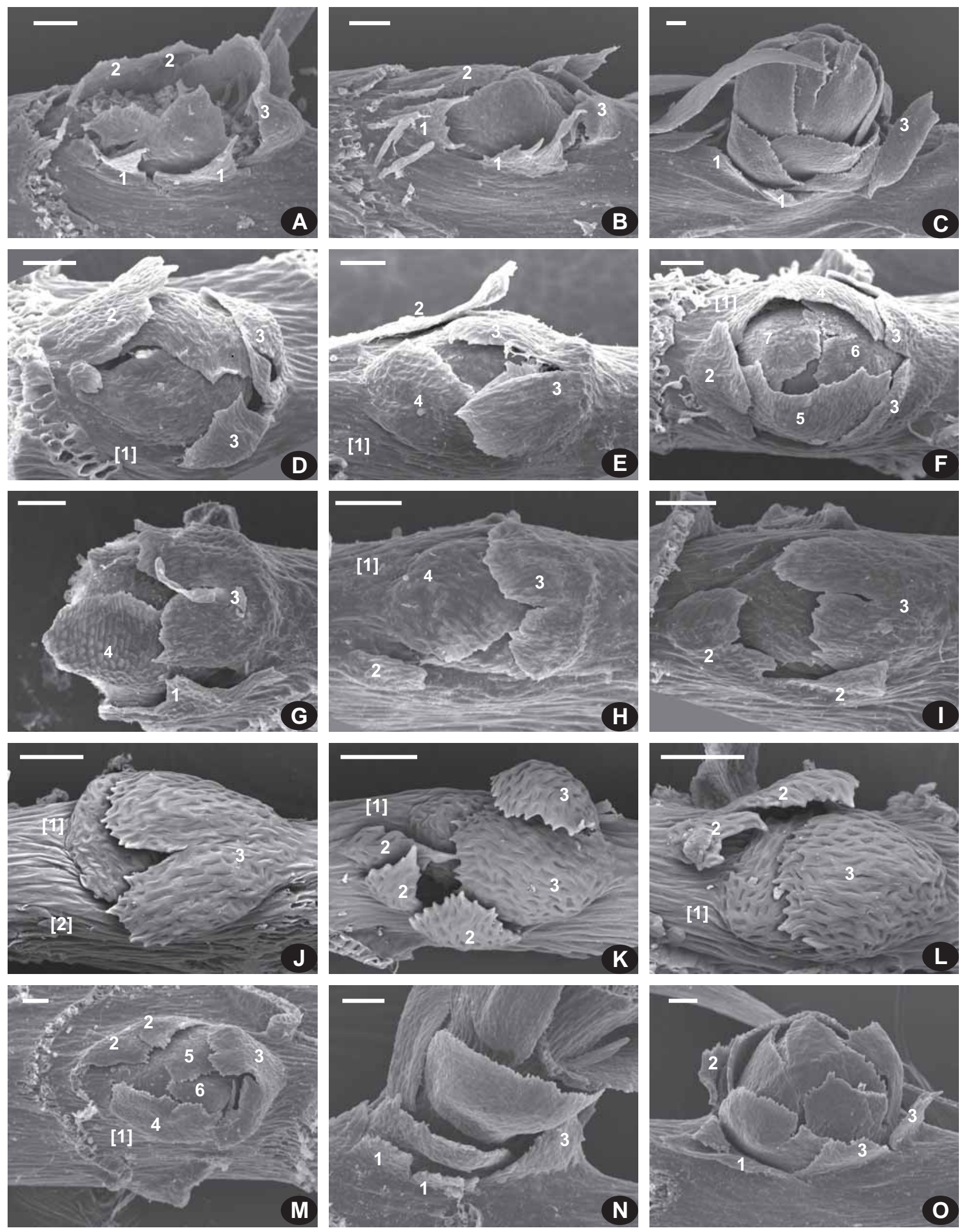

Fig. 3. Branch initials with proximal branch leaves of species of the Lembophyllaceae: A-C: Dolichomitra cymbifolia (Kuril Islands, Bakalin K-45-29-07 MHA); D-F: Lembophyllum divulsum (Hook. f. \& Wilson) Lindb. (Australia, Streimann 59035 MHA); G-I: Camptochaete arbuscula (Sm.) Reichardt (Australia, Streimann 49126 MHA); J-L: Rigodium brachypodium (Chile, Crosby 11893 MHA); M-O: Isothecium subdiversiforme (Japan, Ignatov \& Ignatova 98-580 MHA). Scale bar: $50 \mu \mathrm{m}$ for all. Numerals indicate the proximal leaf number (cf. explanation in Spirina \& Ignatov, 2015), with numbers of reduced leaves given in brackets and parts of compound leaves marked by the same numeral. Stem apex is on the right hand side. 

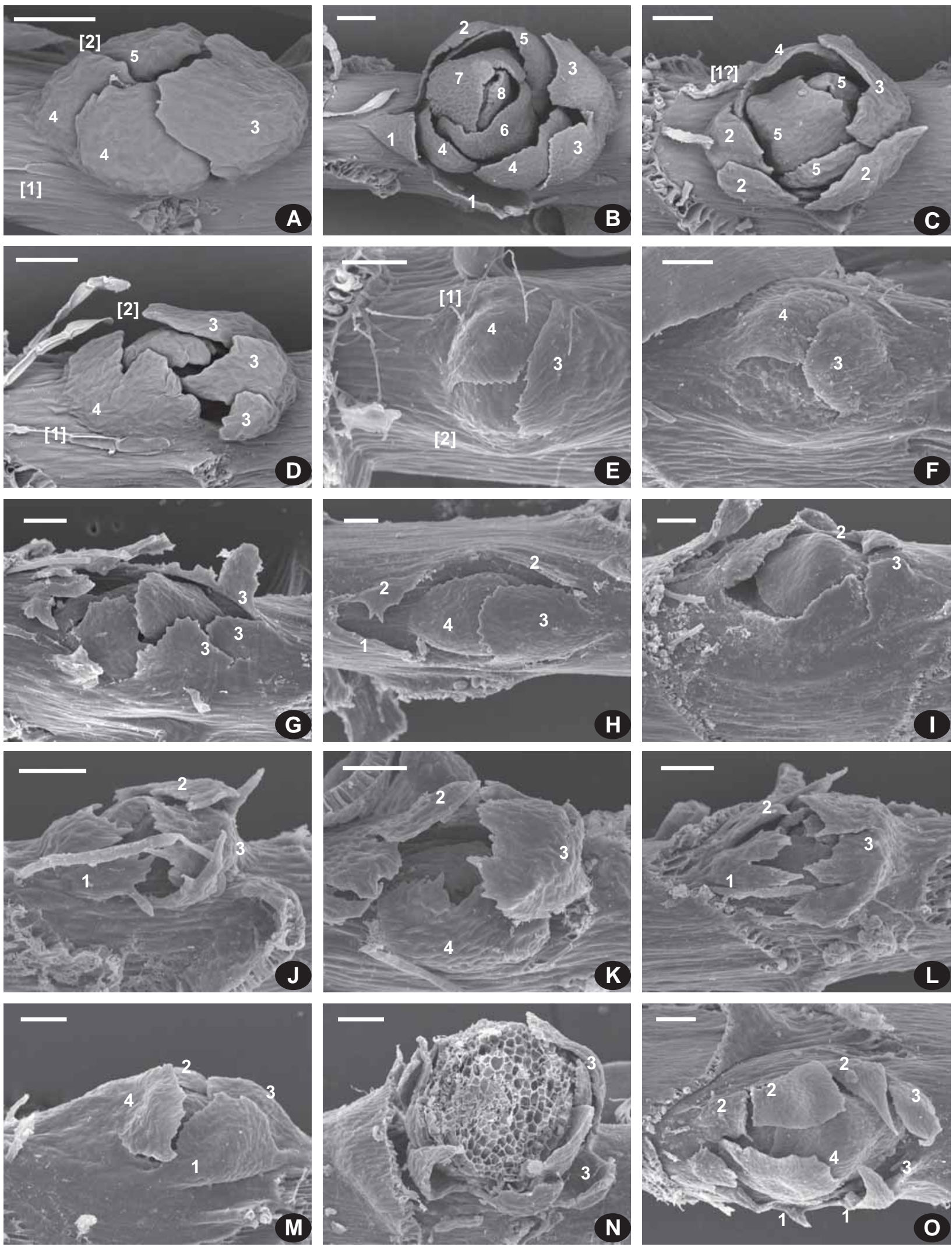

Fig. 4. Branch initials with proximal branch leaves of species of the Lembophyllaceae: A-D: Isothecium alopecuroides (Russia, Ignatov \& Ignatova 56/2, MHA9038346); E-F: Pseudisothecium cristatum (USA, 7 Aug 1989 Ignatov s.n., MHA 9055205); G-I: Pseudisothecium stoloniferum (USA, Shevock 31779, MHA 9055241); J-L: Pseudisothecium myosuroides (Krasnodar, Teplov 2015-029, MHA9038401); M-O: Isothecium hakkodense (Russia, Kuril Islands, Ignatov 06-1125, MHA9109600). Scale bar: $50 \mu \mathrm{m}$ for all. Numerals indicate the proximal leaf number (cf. explanation in Spirina \& Ignatov, 2015), with numbers of reduced leaves given in brackets and parts of compound leaves marked by the same numeral. Stem apex is on the right hand side. 

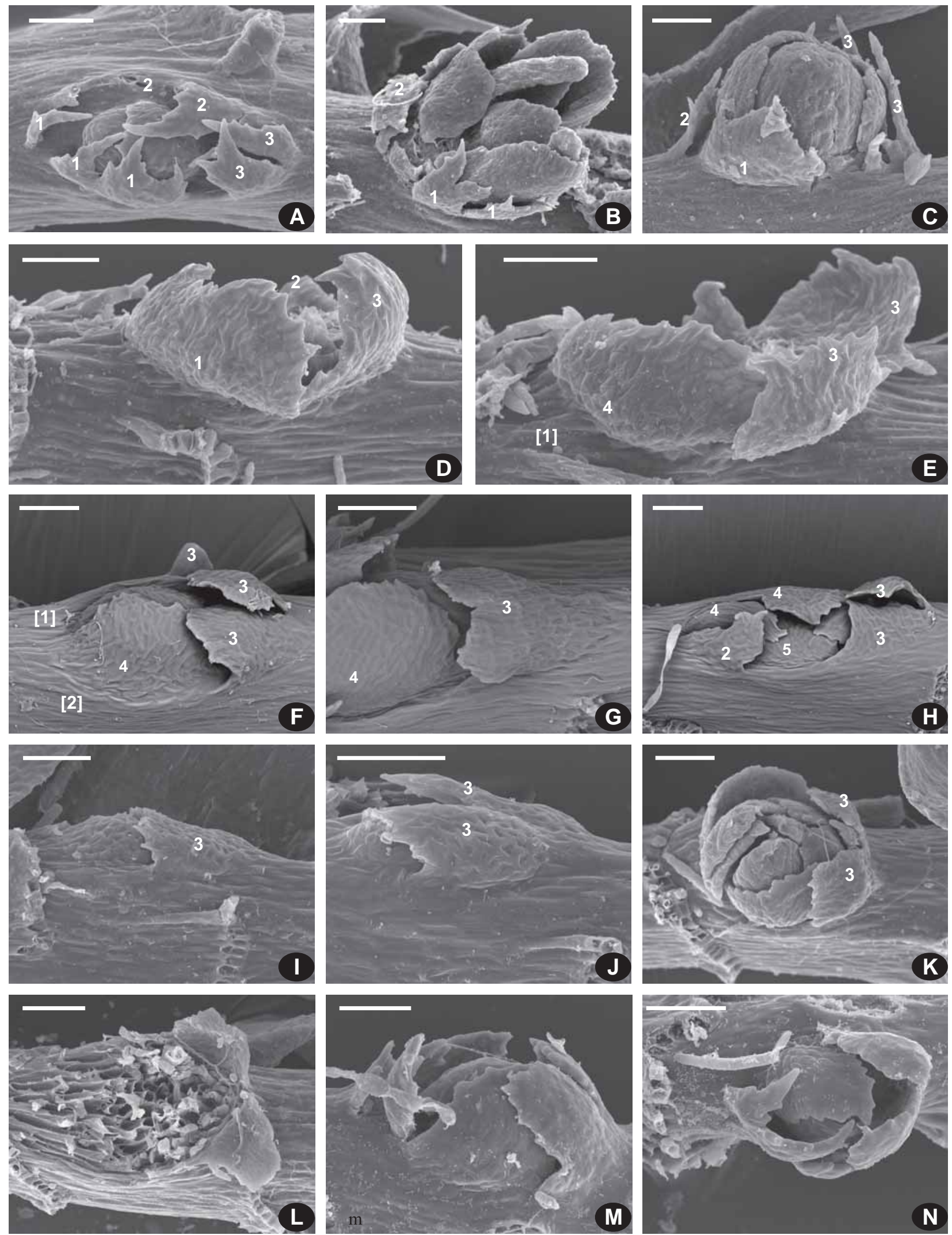

Fig. 6. Branch initials with proximal branch leaves of species of the Lembophyllaceae: A-C: Dolichomitriopsis diversiformis (Russia, Koroteeva 15-10/4-3, MHA); D-E: Dolichomitriopsis cherdantseviae (Russia, Kuril Islands, Ignatov 06-2107, MHA); F-H: Dolichomitriopsis crenulata (Japan, 19 Nov. 1961, Ikegami s.n., MHA); I-L: Bryolawtonia vancouverensis (USA, 8 Aug 1989 , Ignatov \& Norris s.n., MHA9051011); M-N: Tripterocladium leucocladum (Canada, 23 Apr 1979 Schofield s.n., MHA9059395). Scale bar: $50 \mu \mathrm{m}$ for all. Numerals indicate the proximal leaf number (cf. explanation in Spirina \& Ignatov, 2015), with numbers of reduced leaves given in brackets and parts of compound leaves marked by the same numeral. Stem apex is on the right hand side. 
along the margin. Branch primordium is hemispheric, moderately compact.

In Isothecium alopecuroides, Figs. 4A-D, the proximal branch leaves are broadly ovate to suborbicular, and even if they are strongly divided into lobes, e.g., in Figs. $4 \mathrm{C}-\mathrm{D}$, their parts look broad and obtuse. The outermost and subsequent leaves are similar, so when the first or first and second proximal branch leaves are reduced, the existing leaves form the same shape, so branch primordium as a whole looks compact hemispheric.

In Isothecium cristatum (Hampe) H. Rob., Figs. 4E$\mathrm{F}$, the proximal branch leaves are broad, entire, and the first one is in 12 o'clock position, indicating that first and second proximal branch leaves are reduced. Overall shape of branch primordium is low hemispheric.

In Isothecium stoloniferum, Figs. 4G-I, the proximal branch leaves are entire, bilobed, incised to compound, reduced to low ridges beside primordium to welldeveloped, crenulate along margins. Overall shape of branch primordium is loose hemispheric or it is represented by an open group of low elements.

In Isothecium myosuroides, Figs. 4J-L, the proximal branch leaves are incised, laciniate to compound, entire, bilobed, incised to compound, reduced to low ridges beside primordium to well-developed, crenulate along margins. Overall shape of branch primordium is loose hemispheric or it is represented by an open group of low elements.

In Isothecium hakkodense, Figs. 4M-O, the proximal branch leaves are broadly ovate to compound of also highly variable parts, from oblate to narrowly triangular, irregularly crenulate along margins. Overall shape of branch primordium is low hemispheric.

Dolichomitriopsis diversiformis, Figs. $5 \mathrm{~A}-\mathrm{C}$, has compound outermost proximal branch leaves, with incised segments; in observed specimens no complete reduction was observed, i.e. the first proximal leaf was in 4 o'clock position. Overall shape of branch primordium is hemispheric.

In Dolichomitriopsis [new species], Figs. 5D-E, the first and second outer branch leaves may be reduced or present, but in both cases the outermost proximal branch leaves are broadly oblate, serrate, bilobed or entire. Overall shape of branch primordium is low, moderately compact hemisphere.

In Dolichomitriopsis crenulata, Figs. 5F-H, the first and second proximal branch leaves are usually completely reduced, although rarely small lamina of the second leaf is developed; third leaf is bilobed, sometimes with more lobes; overall shape of branch primordium is low hemispheric.

Bryolawtonia, Figs. 5I-K, has relatively invariable branch primordia with the outermost proximal branch leaf in 12 o'clock position, which means the reduction of the first and second proximal branch leaves, typical for Brachytheciaceae (Ignatov, 1999). Contrary to Brachythe- ciaceae, however, this outermost leaf is bilobed. Branch primordium is flat at early stage to compact hemispheric later.

In Tripterocladium, Figs. 5L-N, proximal branch leaves are deeply bilobed, with narrow to broad-ovate lobes; branch primordium in hemispheric, moderately compact.

\section{DISCUSSION}

Lembophyllaceae were found monophyletic both sensu lato, including Heterocladium and Nogopterium $+\mathrm{Ma}$ wenzhangia, and sensu stricto, without these three genera. As the present sampling was not focused specifically on the whole Lembophyllaceae, the controversy of these results cannot be properly discussed here. The more distal position of Heterocladium from Lembophyllaceae was found in some other analyses, e.g. Wang \& Jia (2019). As it was already mentioned in Material and Method section, few ITS sequences strongly different from "typical" (i.e. widely represented in GenBank) were not included in the analyses, though few identical sequences occur in GenBank as well. They are so different that appear in the tree outside not only Isothecium and Lembophyllaceae s.str., but also Lembophyllaceae s.l. The reason of such a hypervariability is interesting, but it requires a special study. Leaving out those sequences, the phylogeny of Lembophyllaceae looks consistent with earlier phylogenies, based on representation of taxa by one or few specimens, and with morphological circumscription of taxa.

The position of the East Asian monospecific Dolichomitra in the basal most position in the Lembophyllaceae s. str. is in agreement with the previously published reconstruction of Quandt et al. (2009) and highly distinctive peristome structure of Dolichomitra: exostome teeth narrow, on dorsal surface smooth below and with high ridges of OPL cell remnants, densely papillose distally; endostome segments narrow and unperforiated, cilia lacking. In addition, the outermost proximal branch leaves in branch primordia are compound and their lobes at early stage of development are spaced, which occurs in some Neckeraceae (Spirina \& Ignatov, 2015) and Heterocladium (Ignatov et al., 2019).

The genera of "core Lembophyllaceae" and some mostly South Hemispheran genera, i.e., Camptochaete, Fallaciella, Fifea, Lembophyllum, Looseria, Neobarbella, Rigodium, and Weymouthia, were found in intermediate clade (Fig. 2) or grade (Fig. 1); such position confirms their distant relationship with any of "Isothecium s.l."-clade, which was the main objective of their inclusion in the present analysis.

The terminal, "Isothecium s.l."-clade will be in the main focus of further discussion. First of all, the temptation to accept Isothecium s.l. so to include all the species of "Isothecium s.1."-clade seems not appropriate, as two out of its three subclades have much better support than when joined as a clade. Second, the genera Bryolawtonia and Tripterocladium have little in common in morphology with either Isothecium alopecuroides, the type 
of the genus, or with the plants of I. myosuroides group. It is worthy mentioning, that the large part in the third subclade, around I. myosuroides, also has high support in both trees.

Such phylogenetic reconstruction commonly leads to splitting genera into more natural entities, as it was suggested for Eurhynchium (Ignatov \& Huttunen, 2002), Neckera (Olsson et al., 2009), Hypnum (Kučera et al., 2019).

The major splitting for the genus Isothecium was suggested already by Grout (1929). Grout found that taxa of the I. myosuroides complex in North America have too little in common with European I. alopecuroides, as the latter species has perfectly erect and symmetric capsules, stronger reduced peristome with poor striolation on dorsal surface of the exostome, low basal membrane, narrow segments and lack of cilia, contrary to Pseudisothecium Grout, in which capsules are slightly inclined to inclined, slightly asymmetric to asymmetric, and the peristome is perfect, with well-developed striolation; endostome has high basal membrane, more broad segments, one or two cilia that can be short to well-developed. In addition, leaves are coarsely serrate all around in species of I. myosuroides affinity vs. subentire in I. alopecuroides. There is also a fairly contrasting difference in proximal branch leaves in branch primordia between I. alopecuroides and I. myosuroides, as in the latter species they are compound, divided into narrow lobes; however, this character is not consistent throughout the I. myosuroides lineage. In I. cristatum, the most basal species in the grade to "core I. myosuroides", proximal branch leaves are entire. The suggestion of Grout on Pseudisothecium did not meet wide acceptance; only Podpera (1954) accepted this genus in Europe. The distinctions between Isothecium and Pseudisothecium are not hundred-percent stable: e.g., I. algarvicum, sister to I. alopecuroides, possesses endostome ciliae (Hedenäs, 1992), while I. cristatum has julaceous habit and less serrate leaves, habitually resembling $I$. alopecuroides rather than $I$. myosuroides.

However, the tree topologies and the nested position of Bryolawtonia and Tripterocladium within the Lembophyllaceae provide an evidence for the necessity of the Pseudisothecium segregation. Bryolawtonia is least similar to other Lembophyllaceae due to subcomplanate foliage, so it was occasionally considered within the Neckeraceae (Norris, 2014). An evidence from morphology for its placement in the Lembophyllaceae is the bilobed proximal branch leaves (Fig. 5I-L).

Tripterocladium is a moss without a strong single costa, so it was historically placed in various families, e.g., in the Sematophyllaceae. This is a small plant, contrary to most other Lembophyllaceae (although some Rigodium species and I. algarvicum comprise other examples of Lembophyllaceae with small plant size).

The East Asian species are habitually similar to North American and European plants; the general difference of East Asian taxa includes the persistent annulus in all species referred to Dolichomitriopsis and Isothecium (I. hakkodense and I. subdiversiforme). Proximal branch leaves do not show anything distinct, except the case of I. subdiversiforme, where proximal branch leaves at early stage are oblate, widely rounded and clearly bilobed, while more developed proximal branch leaves are distally truncate, evenly denticulate along margin. Sporophyte of I. subdiversiforme is "maximally Hypnoid": capsules are strongly curved, exostome teeth are striolate below on the dorsal side, and endostome has perforated segments and developed cilia.

Isothecium hakkodense is variable and sometimes it is difficult to distinguish it from some phenotypes of Dolichomitriopsis; however, its moderately developed peristome, exostome teeth striolate below and endostome having ciliae, in addition to separate position in phylogenetic analysis, also suggests segregating it into a separate genus, rather than placing it in either Isothecium, Pseudisothecium, Dolichomitriopsis, or in the genus segregated for I. subdiversiforme (cf. Table 1).

\section{TAXONOMY}

The formal recognition of lineages discussed above are as follow:

1. Dolichomitriadelphus Ignatova, Fedosov \& Ignatov, gen nov.

Type: Dolichomitriadelphus hakkodensis (Besch.) Ignatova, Fedosov \& Ignatov, comb. nov.

Basyonum: Isothecium hakkodense Besch., Ann. Sci. Nat., Bot., sér. 7, 17: 371. 1893. Type: Nippon Nord, montagne d'Hakkoda, 5 juillet 1893, Faurie 826 (holotype in PC, high-resolution scan: https://science.mnhn.fr/ taxon/species/isothecium/hakkodense; isotype in H-BR!).

Etymology. The name means related to Dolichomitra, an East Asian genus of the Lembophyllaceae.

Diagnosis. Differs from Dolichomitra, Dolichomitriopsis and Isothecium in combination of (1) leaves ovate, with obtuse apices and serrulate margins vs. various in shape, mostly acuminate or, if with obtuse apices, then leaves are oblong-ovate and margins indistinctly crenulate; (2) costa thin, extending to $1 / 3-1 / 2$ the leaf length vs. stout, extending above midleaf; (3) alar group weakly delimited, small vs. well-delimited, medium sized; (4) capsules slightly inclined, slightly asymmetric vs. erect, symmetric.

Species included: monospecific genus.

Dolichomitriadelphus hakkodensis (Besch.) Ignatova, Fedosov \& Ignatov. - Isothecium hakkodense Besch., Ann. Sci. Nat., Bot., sér. 7, 17: 371. 1893.

Plants robust, yellowish-green, glossy. Secondary stems erect to ascending, to $5 \mathrm{~cm}$ long, dendroid, irregularly branched; stipe short; attenuate flagelliform branches absent. Secondary stem leaves imbricate when dry and wet, $1.3-1.5 \times 0.7-0.9 \mathrm{~mm}$, ovate, widest at $1 / 6-1 / 3$ the leaf length, obtuse or bluntly acute, concave; costa single or forked, thin, extending to $1 / 2-3 / 4$ the leaf length; margins serrulate in upper $1 / 2$, entire below; upper laminal cells $15-20 \times 6-7 \mu \mathrm{m}$, moderately thick-walled, slightly 


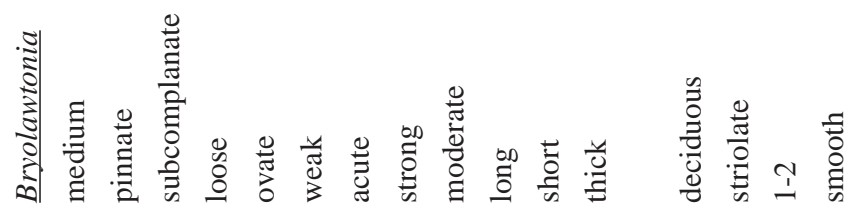

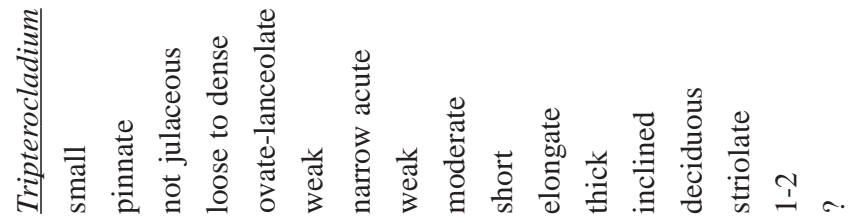

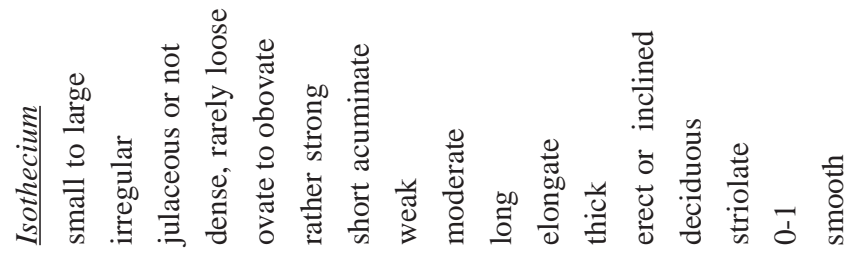

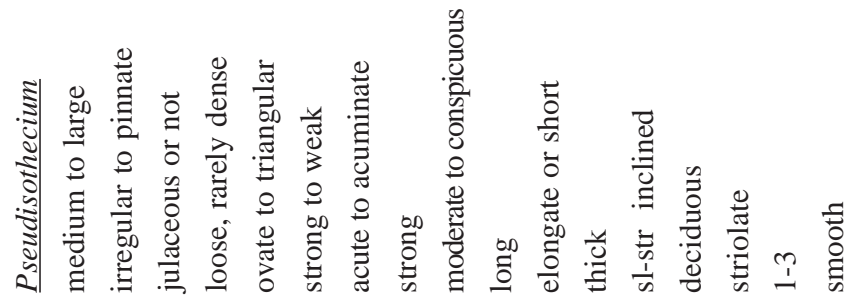

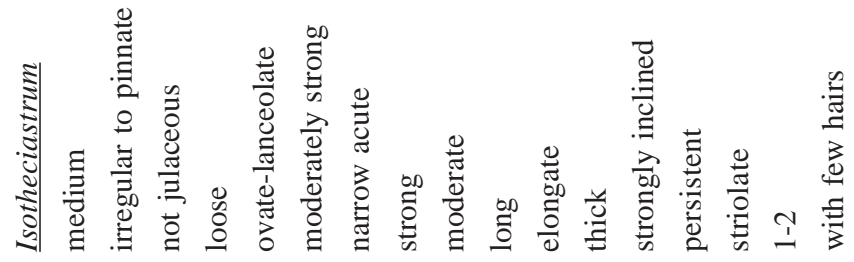

今

원

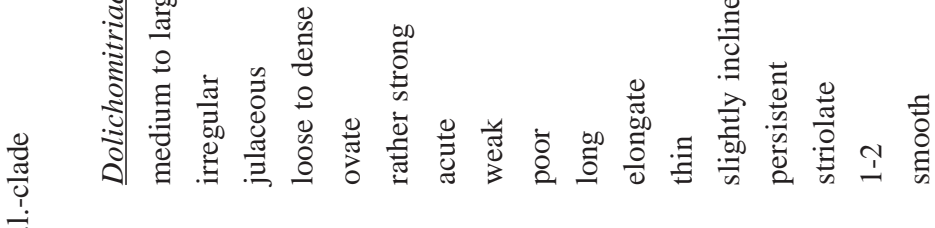

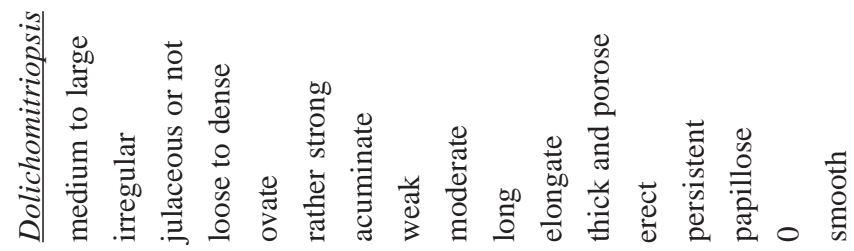

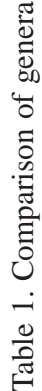

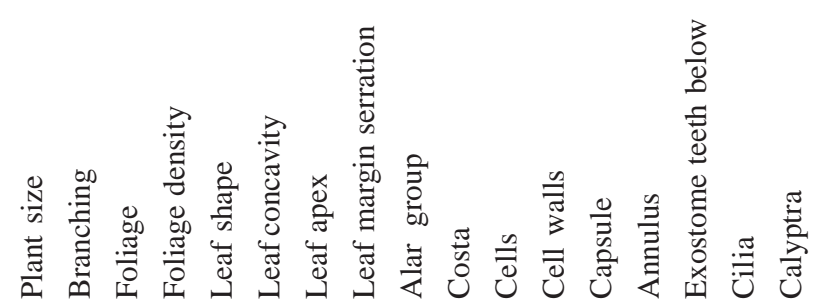



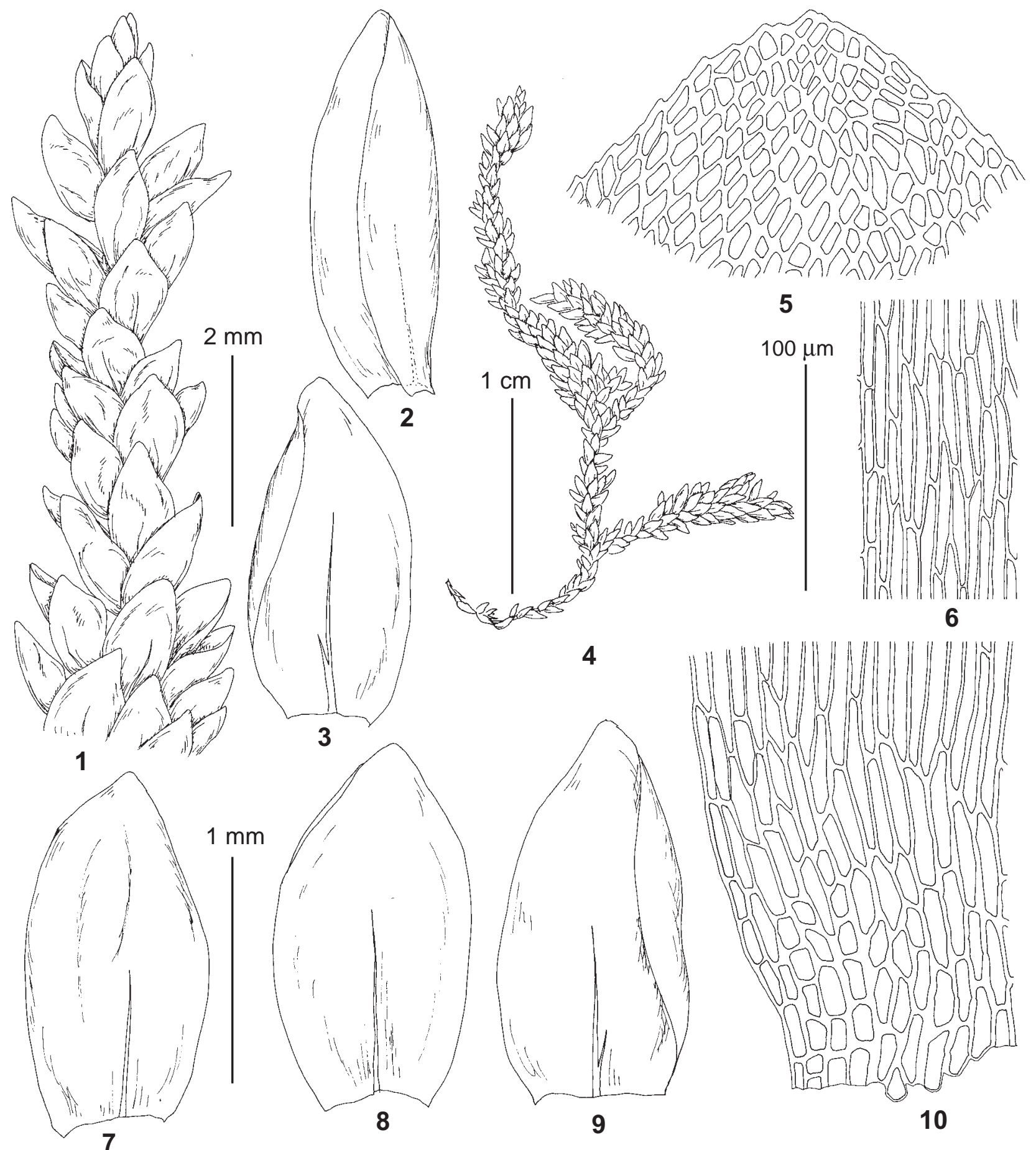

6
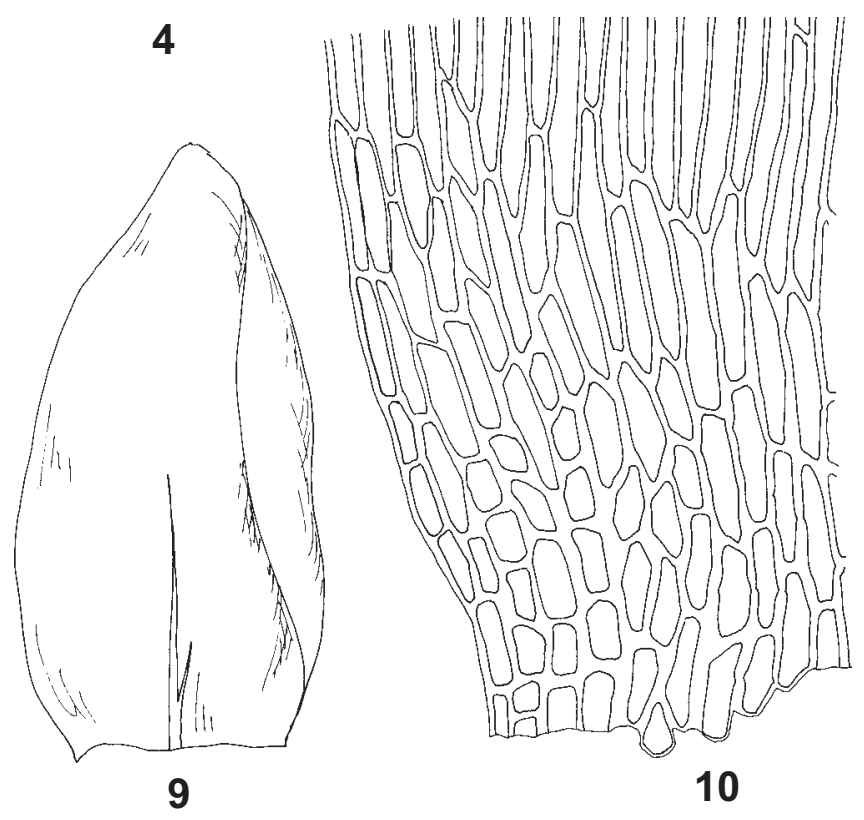

10

Fig. 2. Dolichomitriadelphus hakkodensis (from: Russia, Kuril Islands, Kunashir, Ignatov 06-1284, MHA): 1, 4 - habit, dry; $2-$ 3 - branch leaves; 5 - upper laminal cells; 6 - mid-leaf cells; 7-9 - stem leaves; 10 - basal laminal cells. Scale bars: $1 \mathrm{~cm}$ for 4 ; $2 \mathrm{~mm}$ for $1 ; 1 \mathrm{~mm}$ for $2-3,7-9 ; 100 \mu \mathrm{m}$ for $5-6,10$.

flexuose, eporose; median laminal cells linear, 40-60×5$7 \mu \mathrm{m}$, with moderately thickened walls, porose; basal laminal cells elongate rectangular, $30-40 \times 6-7 \mu \mathrm{m}$, with moderately thickened walls, porose; alar group small, weakly delimited, consisting of rectangular cells. Branch leaves similar to secondary stem leaves but smaller. Dioicous. Gametangia and sporophytes not seen in specimens from Russia. [Setae $0.8-1.2 \mathrm{~cm}$, curved or flexu- ose. Capsules inclined, oblong, symmetric or slightly asymmetric. Exostome teeth ca. $600 \mu \mathrm{m}$ long, striolate below, papillose distally; basal membrane low, segments narrowly perforated, cilia $1-2$, short. Spores $12-15 \mu \mathrm{m}$.]

Distribution and ecology. This species occurs in Japan (Hokkaido, Honshu) and in South Kuril Islands in the Russian Far East. In Russia it grows at altitudes 200$500 \mathrm{~m}$, on rocks and cliffs along streams. 


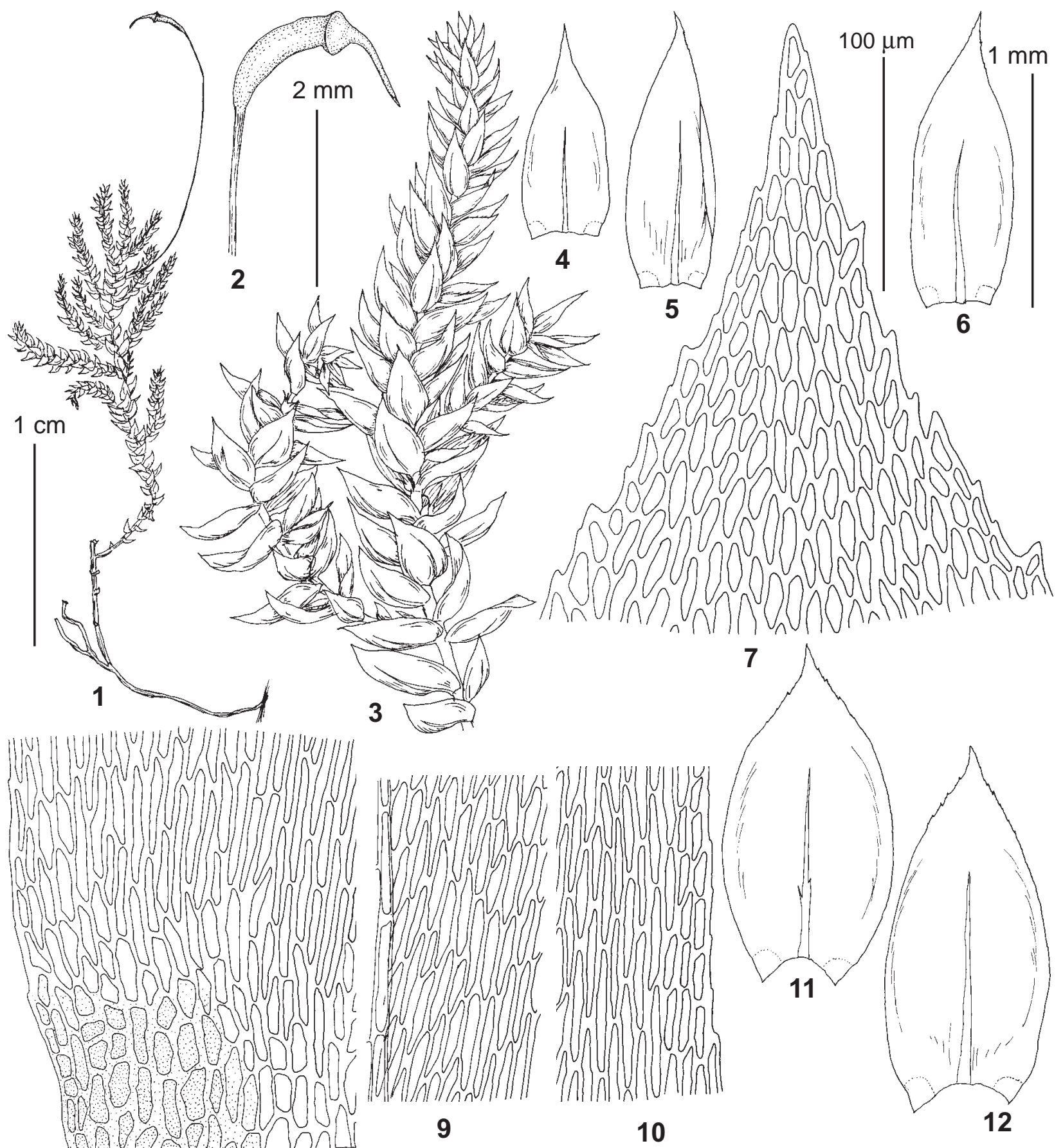

Fig. 2. Isotheciastrum subdiversiforme (from: Japan, Kyushu, Ignatov \& Ignatova 98-580, MHA): 1, 3 - habit, dry; 2 - capsule; 4-6 - secondary branch leaves; 7 - upper laminal cells; 8 - basal laminal cells; 9-10 - mid-leaf cells; 11-12 - primary branch leaves. Scale bars: $1 \mathrm{~cm}$ for $1 ; 2 \mathrm{~mm}$ for $2-3 ; 1 \mathrm{~mm}$ for $4-6,11-12 ; 100 \mu \mathrm{m}$ for $7-10$.

Specimens examined: Russia, Sakhalinskaya Province, Kunashir Island, Ruruj Mt., NW-faced slope, Dal'nij Creek, $44^{\circ} 28^{\prime} \mathrm{N}, 46^{\circ} 06^{\prime}, 250 \mathrm{~m}$ alt., Ignatov 06-1284 (MHA9038396); same place, $500 \mathrm{~m}$ alt., Ignatov 06-1188 (MHA9038398).

Differentiation. The distinction from Dolichomitriopsis crenulata is discussed under this species. Other species of Dolichomitriopsis from the Russian Far East have leaves with attenuate apices, while leaf apex in $D$. hakkodense is obtuse, rounded or, rarely, bluntly acute. D. hakkodense was also confused with Dolichomitra cymbifolia due to imbricate foliage and strongly concave leaves with rounded-obtuse apices; however, they can be recognized by ovate vs. wide elliptical leaves and upper leaf margins serrulate vs. irregularly dentate. 
Isotheciastrum Ignatova, Fedosov \& Ignatov, gen. nov.

Type: Isotheciastrum subdiversiforme (Broth.) Ignatova, Fedosov \& Ignatov

Basionym: Isothecium subdiversiforme Broth., Hedwigia, 38: 237. 1899. Holotype: Nippon Nord, montagne d'Hakkoda, 5 juillet 1893, Faurie 826 (in H-BR!).

Etymology. The name means related to Isothecium, widespread genus of the Lembophyllaceae.

Diagnosis. Differs from Dolichomitra, Dolichomitriopsis and Isothecium in combination of (1) erect-spreading vs. mostly imbricate leaves; (2) leaf margins strongly dentate vs. serrulate, crenulate to subentire or, if dentate, leaf apices rounded; (3) capsules inclined, clearly asymmetric vs. erect or slightly inclined, symmetric or slightly asymmetric; calyptra occasionally with few hairs at base; endostome cilia 1-2, short vs. lacking, rudimentary or, rarely, well-developed. Broadly rounded to truncate proximal branch leaves (Fig. 3M-O) also differentiate it from other species of Isothecium-clade.

Species included: monospecific genus.

Isotheciastrum subdiversiforme (Broth.) Ignatova, Fedosov \& Ignatov, comb. nova - Isothecium subdiversiforme Broth., Hedwigia 38: 237. 1899.

Plants slender, rigid, pale green, slightly glossy. Secondary stems erect to ascending, to $2-5 \mathrm{~cm}$ long, dendroid, irregularly to subpinnately branched; stipe short; attenuate flagelliform branches absent. Secondary stem leaves erect-spreading when dry and wet, $1.3-1.5 \times 0.6-$ $0.7 \mathrm{~mm}$, ovate-lanceolate, widest at mid-leaf, acuminate, moderately concave; costa single, stout, gradually narrowing, occasionally forked, extending to $2 / 3-3 / 4$ the leaf length; margins sharply serrate in upper $1 / 3-1 / 2$, serrulate almost to the base; upper laminal cells $20-30 \times 8-10$ $\mu \mathrm{m}$, slightly flexuose, thick-walled, eporose; median laminal cells sublinear, $25-45 \times 7-8 \mu \mathrm{m}$, not flexuose, thickwalled, weakly porose; basal laminal cells long rectangular, 30-50×7-8 $\mu \mathrm{m}$, thick-walled, weakly porose; alar group small to medium sized, well delimited, consisting of isodiametric, irregular in shape, thick-walled, dark colored cells. Branch leaves similar to secondary stem leaves but smaller. Dioicous. Setae 1.0-1.5 cm, flexuose. Capsules inclined, asymmetric, narrowly oblong-cylindric, brown. Exostome teeth 500-600 $\mu \mathrm{m}$ long, striolate below, papillose above; endostome basal membrane low, segments perforated, cilia 1-2, short. Spores 12-17 $\mu \mathrm{m}$. Calyptra occasionally with few hairs at base.

Distribution and ecology. This species is widespread in Japan and is also known from Taiwan and southern provinces of China. It is not found in Russia yet; we consider it as a provisionary species which can be found in South Kuril Islands. Grows on humus or rocks, rarely on tree bases.

Specimens examined: Japan, Kyushu: Kagoshima Prefecture, Ohnami Lake in Kirishima Range, $31^{\circ} 56^{\prime} \mathrm{N}, 131^{\circ} 22^{\prime} \mathrm{E}$, Ignatov \& Ignatova 98-619 (MW9046234); Miyazaki Prefec- ture, Inohae Valley north of Nichinan, $31^{\circ} 40^{\prime} \mathrm{N}, 130^{\circ} 51^{\prime} \mathrm{E}$, Ignatov \& Ignatova 98-589 (MW9046235); same place, Ignatov \& Ignatova 98-580 (MW9046237); Miyazaki, Minaminaka, Kitago, IV.1946 Noguchi \& Hattori, Musci Japonici Ser. 1 (1947), \#6 (MW9046236).

Differentiation. Isotheciastrum subdiversiforme can be easily recognized due to a unique combination of morphological characters, i.e, erect-spreading leaves with acuminate apices and strongly dentate upper margins, and asymmetric, inclined capsules.

Dolichomitriopsis S. Okamura, Bot. Mag. (Tokyo) 25: 66. 1911.

Type: Dolichomitriopsis crenulata S. Okamura

The genus is characterized by ovate-lanceolate or oblong-ovate leaves, mainly acuminate, except for the type speciesof the genus which has leaves with widely obtuse apices. Other diagnostic characters of the genus include (1) erect, symmetric capsules; (2) calyptra extending to the middle of capsule; (3) annulus persistent (consisting of small cells); (4) exostome teeth evenly and densely papillose; (5) endostome basal membrane low, segments not perforated, cilia lacking.

Dolichomitriopsis crenulata S. Okamura, Bot. Mag. (Tokyo) 25: 66. 3. 1911.

Plants medium-sized, yellowish-green, slightly glossy, forming loose tufts. Secondary stems ascending, to $5 \mathrm{~cm}$ long, irregularly branched, stipe indistinct; branches occasionally flagelliform-attenuate. Secondary stem leaves imbricate when dry and wet, 1.6-1.8(-2.0) $\times 0.8-1.0 \mathrm{~mm}$, oblong-ovate or obovate, widest at $1 / 3-2 / 3$ the leaf length, widely obtuse, strongly concave; costa single, stout, gradually narrowing, occasionally forked, extending to $2 / 3$ $4 / 5$ the leaf length; margins widely incurved, crenulate or almost entire in upper $1 / 2$, slightly uneven below; upper laminal cells vermiform, $20-30 \times 8-10 \mu \mathrm{m}$, thick-walled, eporose; median laminal cells sublinear, flexuose, forming oblique rows, 35-50×6-7 $\mu \mathrm{m}$, with moderately thickened walls, eporose; basal laminal cells sublinear, 40$55 \times 8-9 \mu \mathrm{m}$, thick-walled, eporose or indistinctly porose; alar group small to medium-sized, well-delimited, consisting of isodiametric, irregular in shape, thick-walled, dark colored cells. Branch leaves similar to secondary stem leaves but smaller.

Dioicous. Gametangia and sporophytes unknown in Russia. [Perichaetia on secondary stems. Setae flexuose when dry, 5-7 mm long. Capsules erect, symmetric, oblong-cylindric, smooth, brown. Annulus consisting of small cells. Exostome teeth ca. $300 \mu \mathrm{m}$ long, papillose throughout; endostome basal membrane low. Spores 10$13 \mu \mathrm{m}]$.

Distribution and ecology. This species was considered as an endemic of Japan (Hokkaido, Honshu). It is newly reported from Russia, South Kuril Islands, Iturup Island. It was collected in dwarf-shrub \& herb dominated tundra in place with late snow melting, in crevices between boulders. 


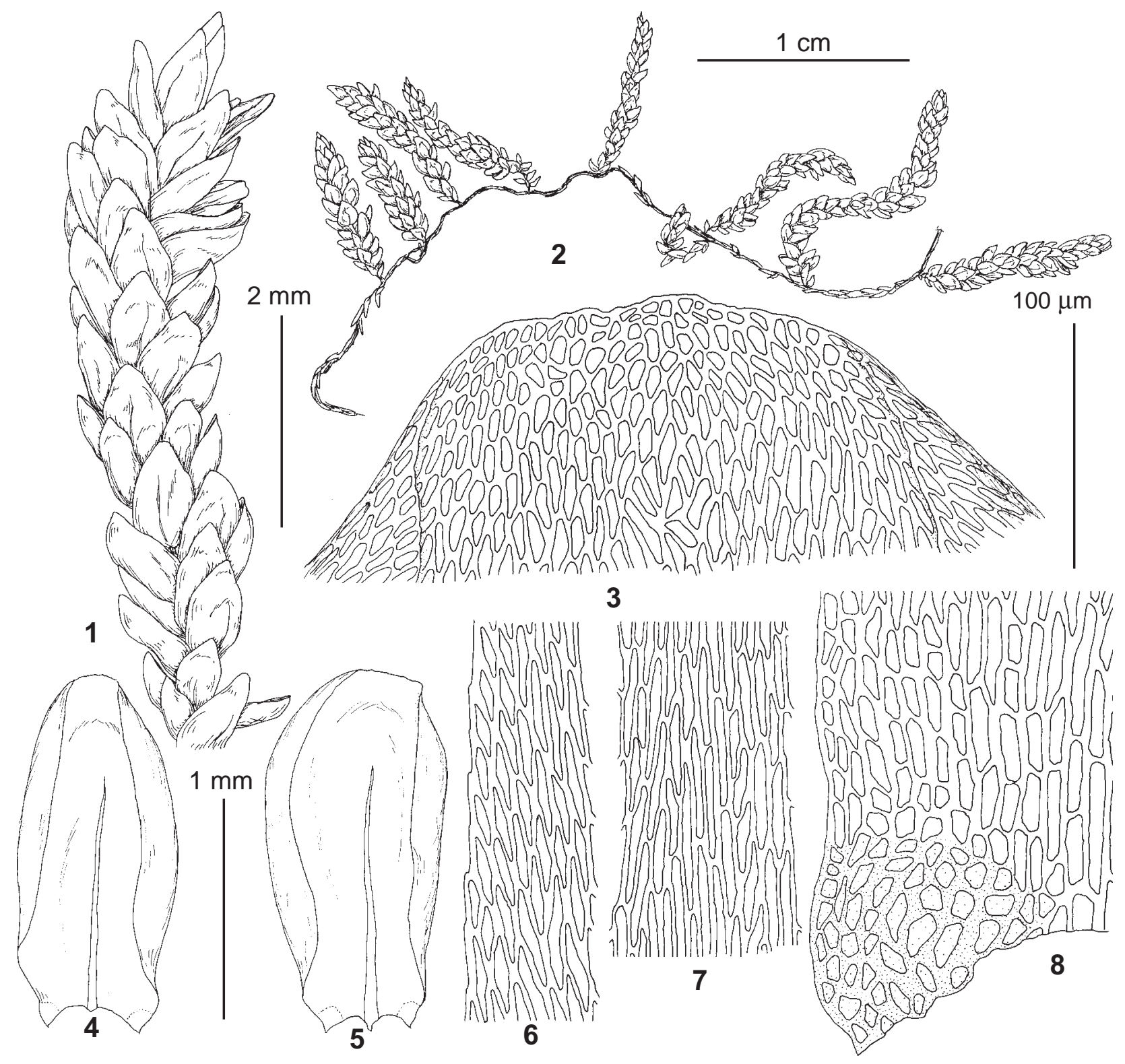

Fig. 2. Dolichomitriopsis crenulata (from: Russia, Kuril Islands, Iturup, Bakalin K-16-45-07, MHA9038397): 1-2 - habit, dry; 3 - upper laminal cells; 4-5 - leaves; 6-7 - mid-leaf cells; 8 - basal laminal cells. Scale bars: $1 \mathrm{~cm}$ for 2; $2 \mathrm{~mm}$ for 1; $1 \mathrm{~mm}$ for 4-5; $100 \mu \mathrm{m}$ for $3,6-8$.

Specimen examined: Russia, Sakhalinskaya Province, Iturup Island, Bigatyr Range NW-faced macroslope, Bakalin $K$ 16-45-07 (MHA9038397).

Differentiation. In leaf shape (oblong-ovate, widely obtuse, strongly concave) and imbricate foliage D. crenulata is similar to Dolichomitra cymbifolia; however, leaf margins are indistinctly crenulate in $D$. crenulata vs. strongly and irregularly dentate in the latter species. $D$. crenulata was also confused with Dolichomitriadelphus hakkodense; the differences between these two species include strongly vs. moderately concave leaves; oblongovate or obovate vs. ovate leaf shape; widely vs. narrowly obtuse leaf apices; and indistinctly crenulate vs. serrulate upper leaf margins.
Dolichomitriopsis cherdantsevae Ignatov \& Ignatova, sp. nov.

Type: Russia, Primorsky Territory, Livadijskaya (Pidan) Mt., left tributary of Pryamoj Klyuch, $43^{\circ} 06^{\prime} \mathrm{N}$, $132^{\circ} 41^{\prime} \mathrm{E}$, alt. $450 \mathrm{~m}$, on rocks in forest, 28.VIII. 2007, Ignatov 07-160. Holotype MW9037078, isotypes MHA9109603, LE.

Diagnosis. Differs from Dolichomitriopsis diversiformis in loose vs. dense tufts; secondary stems longer, to $10 \mathrm{~cm}$ vs. 3-4 cm long, subpinnate vs. dendroid branching; secondary stem and branch leaves erect-spreading vs. imbricate when dry; secondary stem and branch leaves not variable in shape, widest at 1/4-1/2 the leaf length 


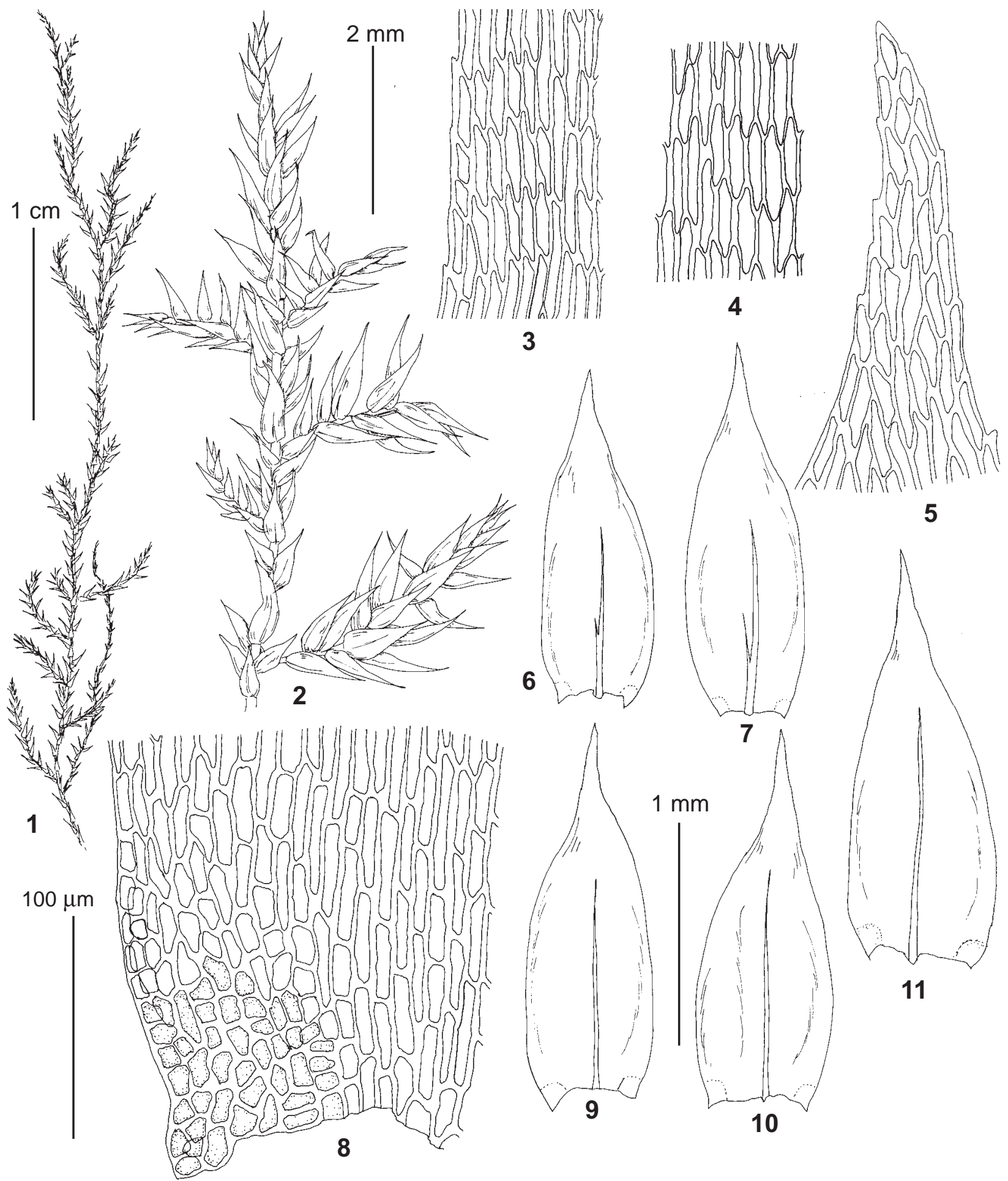

Fig. 2. Dolichomitriopsis cherdantsevae (from: Russia, Primorsky Territory, Pidan Mt., Ignatov \& Ignatova 06-2397, MW9037075): 1-3 - habit, dry; 3-4 - mid-leaf cells; 5 - upper laminal cells; 6-7 - branch leaves; 8 - basal laminal cells; 9-11 stem leaves. Scale bars: $1 \mathrm{~cm}$ for $1 ; 2 \mathrm{~mm}$ for $2 ; 1 \mathrm{~mm}$ for $6-7,9-11 ; 100 \mu \mathrm{m}$ for $3-5,8$.

vs. variable in shape, widest at 1/3-2/3 the leaf length; and attenuate flagelliform branches present vs. absent.

Etymology. The species name is given in honor of Valentina Yakovlevna Cherdantseva (1939-2013), Russian bryologist who worked in Vladivostok and made a great impact into the knowledge of the moss flora of Primorsky Territory.
Plants slender, pale-green, slightly glossy, forming loose tufts. Secondary stems erect to ascending, to $10 \mathrm{~cm}$ long, irregularly to subpinnately branched; stipe short or absent; attenuate-flagelliform branches often present. Secondary stem leaves erect-spreading when dry and wet, $1.5-1.8 \times 0.5-0.6 \mathrm{~mm}$, ovate-lanceolate, acuminate, slightly concave in lower half; costa single, gradually narrow- 

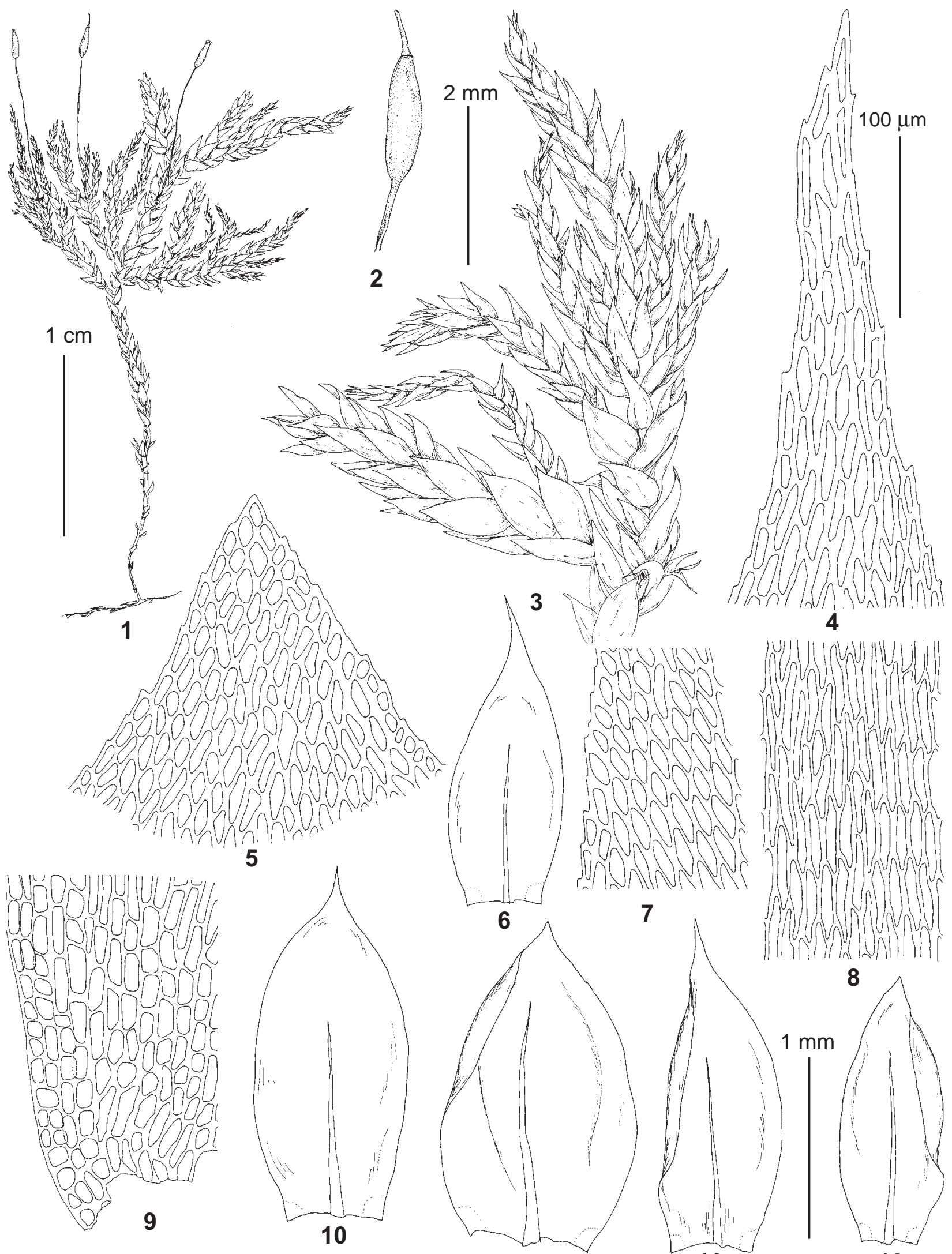

11
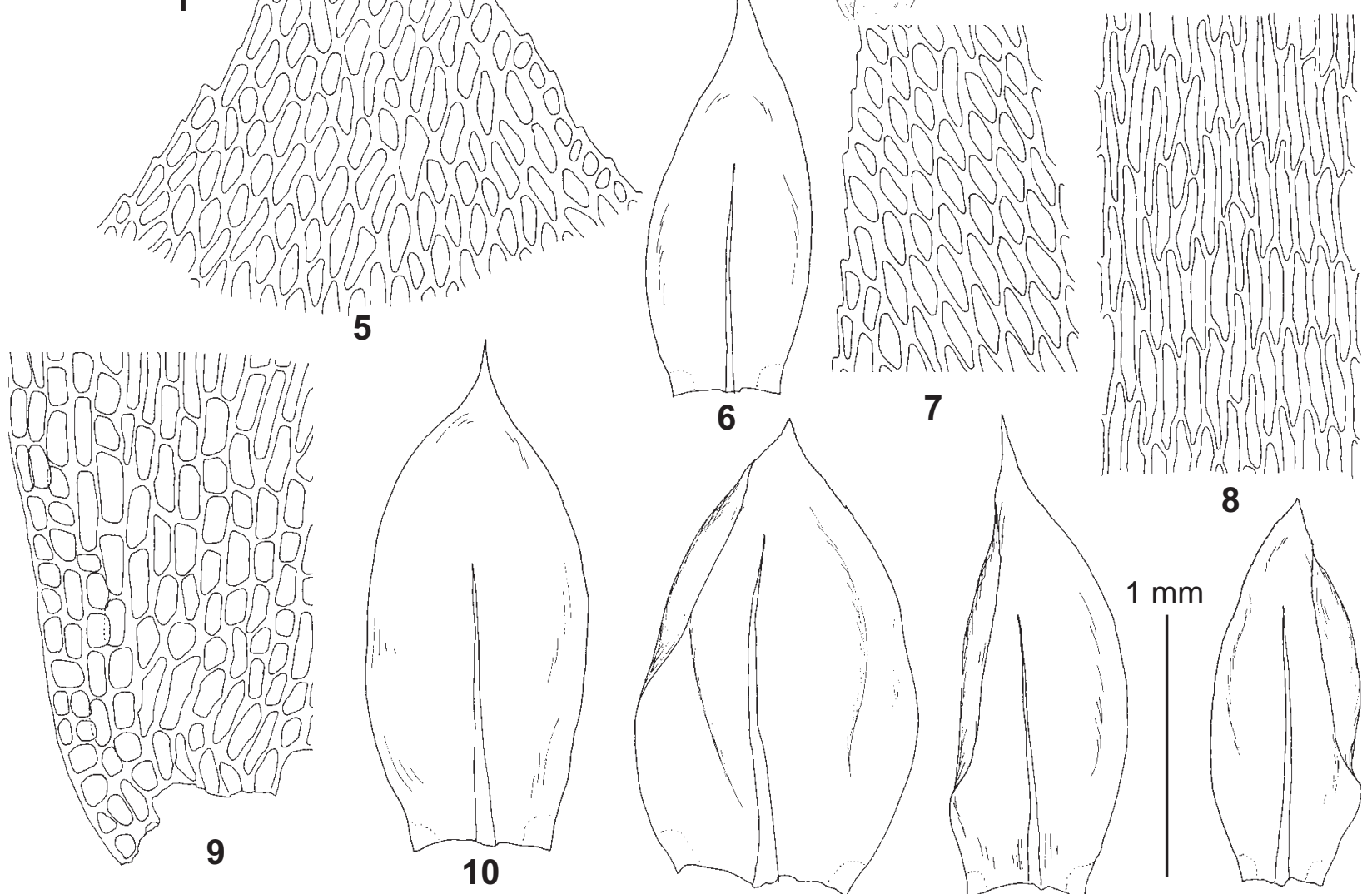

12

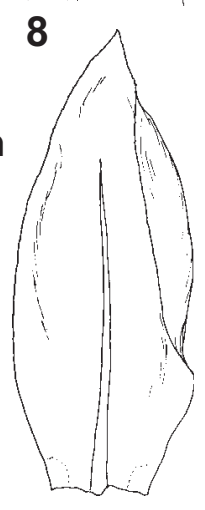

Fig. 2. Dolichomitriopsis diversiformis (from: Russia, Kuril Islands, Kunashir, Ignatov 06-1847, MHA): 1, 3 - habit, dry; 2 capsule; 4-5 - upper laminal cells; 6, 12-13 - branch leaves; 7-8 - mid-leaf cells; 9 - basal laminal cells; 10-11 - stem leaves. Scale bars: $1 \mathrm{~cm}$ for $1 ; 2 \mathrm{~mm}$ for $2-3$; $1 \mathrm{~mm}$ for $6,10-13,7-9 ; 100 \mu \mathrm{m}$ for $4-5,7-9$. 
ing, occasionally forked, extending to $1 / 2-3 / 4$ the leaf length; margins plane, serrulate in upper $1 / 2$, weakly serrulate almost to the base; upper and median laminal cells linear, $40-80 \times 7-8 \mu \mathrm{m}$, thick-walled, eporose or weakly porose; basal laminal cells long rectangular, 40$70 \times 7-9 \mu \mathrm{m}$, thick-walled, weakly porose; alar group well delimited, consisting of isodiametric, irregular in shape, thick-walled, dark colored cells. Branch leaves similar to secondary stem leaves but smaller.

Dioicous. Perichaetia numerous on secondary stems. Perichaetial leaves from oblong sheathing base narrowed into long triangular acumen, acumina spreading. Male plants and sporophytes not seen.

Distribution and ecology. This species is endemic for the Russian Far East. It was collected several times at one locality, on slope of Pidan (Livadijskaya) Mt., at 450$900 \mathrm{~m}$ alt., in mixed conifer \& broadleaved forest, on rocks covered with mosses.

Other specimen examined: Russia, Primorsky Territory, Pidan (Livadijskaya) Mt., $43^{\circ} 05^{\prime} \mathrm{N}, 132^{\circ} 41^{\prime}, 900 \mathrm{~m}$ alt., Ignatov \& Ignatova 06-2107 (MHA9109604 \& MW9037077); same place, $43^{\circ} 06^{\prime} \mathrm{N}, 132^{\circ} 41^{\prime} \mathrm{E}$, alt. 400-500 m, Ignatov \& Ignatova 06-2397 (MW9037075).

Dolichomitriopsis diversiformis (Mitt.) Nog., J. Jap. Bot 22: 83. 1948.

Plants medium-sized, pale-green or yellowish-green, slightly glossy, forming dense tufts. Secondary stems erect, 3.5-4 cm long, dendroid, stipe short; stoloniform branches absent. Secondary stem leaves imbricate when dry and wet, $1.2-1.3(-1.7) \times 0.6-0.7(-0.9) \mathrm{mm}$, ovate, oblong or obovate, widest at 1/3-2/3 the leaf length, acuminate, concave; costa single, stout, gradually narrowing, occasionally forked, extending to $1 / 2-5 / 6$ the leaf length; margins plane, serrulate in upper $1 / 2$, entire below; upper laminal cells rhomboidal to oblong-elliptical, $12-20 \times 8-10 \mu \mathrm{m}$, thick-walled, eporose; median laminal cells sublinear, slightly flexuose, $20-40 \times 5-6 \mu \mathrm{m}$, thick-walled, eporose; basal laminal cells long rectangular, $25-45 \times 6-7 \mu \mathrm{m}$, thickwalled, eporose; alar group small to medium-sized, welldelimited, consisting of isodiametric, irregular in shape, thick-walled, dark colored cells. Branch leaves similar to secondary stem leaves but smaller.

Dioicous. Perichaetia numerous on secondary stems and branches. Perichaetial leaves from oblong sheathing base narrowed into long triangular acumen, acumina spreading. Setae straight, 7-10 mm long. Capsules erect, symmetric, oblong-cylindric, smooth, reddish-brown. Annulus consisting of small cells. Exostome teeth 250 $(-300) \mu \mathrm{m}$ long, papillose throughout; endostome basal membrane low; segments narrow, not perforated; cilia absent. Spores 14-18 $\mu \mathrm{m}$.

Distribution and ecology. In the Russian Far East D. diversiformis is known from the South Kuril Islands and Primorsky Territory; it grows at altitudes from sea level to $695 \mathrm{~m}$, in broadleaved, conifer and mixed forests, and occasionally on meadows. It was collected from tree bases (of Sorbus, Alnus, Betula, Quercus, and Abies), as well as on rocks and rock outcrops.

Specimens examined: Russia: Sakhalinskaya Province, Is-

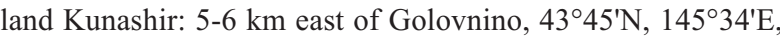
18.VII.1990 Nedoluzhko s.n. (MHA9109601); cape Mysovyj, $44^{\circ} 17^{\prime} \mathrm{N}, 146^{\circ} 17^{\prime} \mathrm{E}, 40 \mathrm{~m}$ alt., Ignatov 06-1847 (MW9037073); vicinities of Tretjakovo Settlement, $43^{\circ} 58^{\prime} \mathrm{N}, 145^{\circ} 39^{\prime} \mathrm{E}, 123 \mathrm{~m}$ alt., Koroteeva 15-10/7-7 \& 15-10/4-3 (MHA9049327 \&

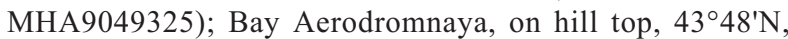
146ํ5'E, 11.IX.2006 Nyushko Sh-28-06f (MHA 9109597); Ruruy Mt., $44^{\circ} 28^{\prime} \mathrm{N}, 146^{\circ} 06^{\prime} \mathrm{E}, 450 \mathrm{~m}$ alt., Ignatov 06-1125 (MHA9109600); Island Shikotan: area of Malokurilsk Village, $43^{\circ} 52^{\prime} \mathrm{N}, 146^{\circ} 51^{\prime} \mathrm{E}, 100 \mathrm{~m}$ alt., Bakalin K-37-3-07 (MHA9109598); Primorsky Territory: Vladivostok Area, near Lyanchikhe Settl., 26.IX.1950 Voroshilov s.n. (MHA9109605);

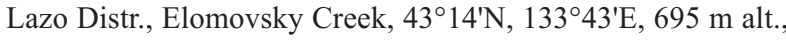
Ignatov \& Ignatova 13-1742 (MHA9109599).

Differentiation. Differences between $D$. diversiformis and $D$. cherdantsevae are given in the diagnosis of the latter species. Isotheciastrum subdiversiforme has leaves of similar shape; however, in that species leaves are erectspreading vs. imbricate in $D$. diversiformis, with sharply serrate vs. serrulate margins; furthermore, if sporophytes are present, these species are easily recognized due to asymmetric, inclined vs. symmetric, erect capsules.

Dolichomitra Broth., Nat. Pflanzenfam. 1(3): 867. 1907.

The genus is characterized by combination of robust plants; imbricate foliage; widely ovate, strongly concave leaves with rounded apices and irregularly dentate upper margins; erect, symmetric capsules; deciduous annulus; exostome teeth smooth below, densely papillose in upper $2 / 3$; endostome basal membrane moderately low, segments not perforated, cilia lacking.

The genus includes single species.

Dolichomitra cymbifolia (Lindb.) Broth., Nat. Pflanzenfam. I(3): 868. 636. 1907.

Plants robust, pale-green or yellowish-green, forming loose tufts. Secondary stems erect, to $8 \mathrm{~cm}$ long, curved above, irregularly branched, stipe distinct; flagelliform-attenuate branches occasionally present. Secondary stem leaves imbricate when dry and wet, 1.6-2.0×1.6$1.3 \mathrm{~mm}$, broadly oblong, oblong-elliptical or almost round, widest at mid-leaf, widely obtuse, strongly concave; costa single, stout, gradually narrowing, often forked, extending to 2/3-3/4 the leaf length; margins widely incurved, irregularly dentate at rounded apical part, serrate at upper $1 / 3$, entire below; upper laminal cells vermiform, $20-25 \times 8-10 \mu \mathrm{m}$, with unevenly thickened walls, with pores near cell ends; median laminal cells sublinear, not flexuose, $35-45 \times 6-7 \mu \mathrm{m}$, thickwalled, strongly porose; basal laminal cells sublinear, 40 $50 \times 8-9 \mu \mathrm{m}$, thick-walled, strongly porose; alar group indistinct or weakly differentiated, small. Branch leaves similar to secondary stem leaves.

Dioicous. Archegonia on secondary stems. Male plants and sporophytes unknown in Russia. [Setae flex- 


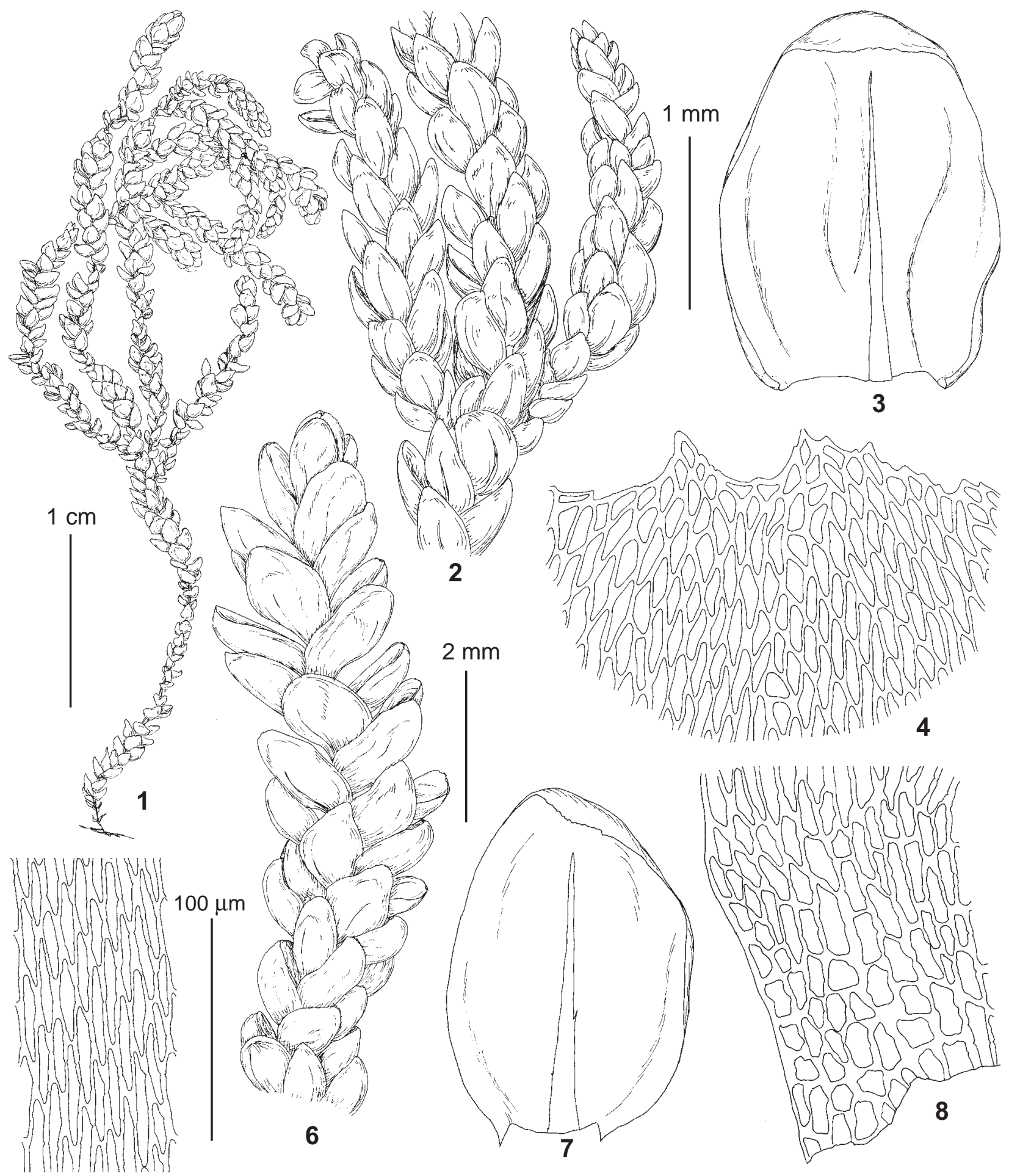

5

Fig. 2. Dolichomitra cymbifolia (from: Russia, Kuril Islands, Shikotan, Bakalin K-42-4-07, MW9046187): 1-2, 6 - habit, dry; 3, 7 - branch leaves; 4 - upper laminal cells; 5 - mid-leaf cells; 8 - basal laminal cells. Scale bars: $1 \mathrm{~cm}$ for 1;2 mm for 2, 6; $1 \mathrm{~mm}$ for 3,$7 ; 100 \mu \mathrm{m}$ for $4,5,8$.

uose when dry, 2.0-2.5 cm long. Capsules erect, symmetric, oblong-cylindric, smooth, brown. Annulus deciduous. Exostome teeth ca. $500 \mu \mathrm{m}$ long, smooth below, papillose in upper $2 / 3$; endostome basal membrane low, segments keeled, not perforated, cilia lacking. Spores 10 $15 \mu \mathrm{m}]$.
Distribution and ecology. Dolichomitra cymbifolia is known from Japan, Korea, China, and Taiwan; it is newly reported from South Kuril Islands in Russia. Grows in forests, on rocks covered with humus layer; in Shikotan Island it was collected at $250 \mathrm{~m}$ a.s.1., in grass community intermingled with Juniper thickets, on a ledge of wet cliff. 
Specimens examined: Russia, South Kuril Islands, Shiko-

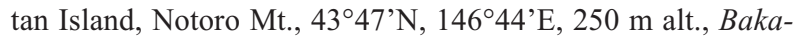
lin K-45-29-07 (MHA, MW9046191).

Differentiation. Dolichomitra cymbifolia can be recognized by robust plants; imbricate foliage; oblong-elliptical to almost round, strongly concave leaves with widely incurved margins; widely obtuse apices; leaf margins irregularly serrate only at apex and serrulate in upper $1 / 2$; and almost indistinct alar groups; strongly porose median and basal cells are also unique for Dolichomitra among the Lembophyllaceae in the Russian Far East. Differences from Dolichomitriadelphus hakkodensis are discussed under that species.

KEY FOR IDENTIFICATION OF LEMBOPHYLLACEAE IN THE RUSSIAN FAR EAST AND NEIGHBORING TERRITORIES

1. Leaves ovate, wide elliptical, round or oblong-ovate, rounded at apex .. 2

- Leaves ovate-lanceolate or ovate, rarely obovate, acute or acuminate. .. 4

2. Leaves wide elliptical or round, irregularly dentate at apex; laminal cells strongly porose

Dolichomitra cymbifolia

- Leaves ovate or oblong-ovate, serrulate or crenulate to almost entire at apex; laminal cells eporose or weakly porose 3

3. Leaves oblong-ovate, cymbiform, crenulate to almost entire at apex ............ Dolichomitriopsis crenulata

- Leaves ovate, cochleariform, serrulate at apex ....... Dolichomitriadelphus hakkodensis

4(1). Leaves strongly dentate in distal part; capsules inclined, asymmetric.

[Isotheciastrum subdiversiforme]

- Leaves serrulate in distal part; capsules erect, symmetric or sporophytes absent. 5

5. Leaves imbricate when dry, widest at $1 / 3-2 / 3$ the leaf length; attenuate-flagelliform branches absent; capsules erect, symmetric

Dolichomitriopsis diversiformis

- Leaves erect-spreading when dry, widest at 1/3-1/2 the leaf length; attenuate-flagelliform branches occasionally present; sporophytes unknown

Dolichomitriopsis cherdantsevae

\section{OTHER PROPOSED NOMENCLATURE CHANGES}

Pseudisothecium Grout Moss Fl. N. Amer. 3: 12. 1928. Type: Pseudisothecium myosuroides (Brid.) Grout

Plants medium-sized to robust. Secondary stems dendroid to pinnately branched, branches often arching downward, in some species attenuate-flagelliform. Leaves ovate to ovate-lanceolate or ovate-triangular, acute or acuminate; margins serrate to coarsely so, rarer serrulate; laminal cells short-elongate to elongate, thickwalled, alar cells numerous. Capsules suberect to inclined, more or less symmetric to distinctly curved; operculum rostrate; annulus deciduous; exostome teeth striolate be- low, papillose above; basal membrane high, segments narrow, perforated, ciliae 1-3, usually long.

Other species included:

Pseudisothecium cardotii (Kindb.) Ignatova, Fedosov \& Ignatov, comb. nov. - Isothecium cardotii Kindb., Cat. Canad. P1., Musci 275-276. 1892.

Pseudisothecium cristatum (Hampe) Ignatova, Fedosov \& Ignatov, comb. nov. - Leptohymenium cristatum Hampe, Linnaea 30(4): 459-460. 1860. — Isothecium cristatum (Hampe) H. Rob., Bryologist 65(2): 95. 1962 [1963].

Pseudisothecium holtii (Kindb.) Ignatova, Fedosov \& Ignatov, comb. nov. - Isothecium holtii Kindb., Rev. Bryol. 22: 83. 1895.

Pseudisothecium interludens (Stirt.) Ignatova, Fedosov \& Ignatov, comb. nov. - Isothecium interludens Stirt., Ann. Scott. Nat. Hist. 9(35): 178. 1900.

Pseudisothecium montanum (Draper et al.) Ignatova, Fedosov \& Ignatov, comb. nov. - Isothecium montanum Draper, Hedenäs, M. Stech, Tina Lopes \& SimSim, Bot. J. Linn. Soc. 177(3): 431. 2015.

Pseudisothecium prolixum (Mitt.) Ignatova, Fedosov \& Ignatov, comb. nov. - Leskea prolixa J. Proc. Linn. Soc., Bot. 8: 7. 1. 1864. — Echinodium prolixum (Mitt.) Broth., Nat. Pflanzenfam. I(3): 1217. 1909. — Isothecium prolixum (Mitt.) M. Stech, Sim-Sim, Tangney \& D. Quandt, Organisms Diversity Evol. 8: 290. 2008.

Pseudisothecium stoloniferum (Brid.) Grout.

\section{ACKNOWLEDGEMENTS}

We cordially thank J. Shevock for improving English of the paper. The work on SEM was performed at User Facilities Center of M.V.Lomonosov Moscow State University under financial support of Ministry of Education and Science of Russian Federation. The molecular study was supported by RSF RSF18-14-00121.

\section{LITERATURE CITED}

BROTHERUS, V.F. 1907. Bryales, in part. I(3). - In: Engler, H.G.A. \& K. Prantl (eds.) Die Natürlichen Pflanzenfamilien. Engelmann, Leipzig: 865-960.

CHERDANTSEVA, V.YA.†, O.YU. PISARENKO, M.S. IGNATOV, E.A. IGNATOVA, V.E. FEDOSOV, S.V. DUDOV \& V.A. BAKALIN. 2018. Mosses of the southern Russian Far East, an annotated check-list. Botanica Pacifica 7(2): 53-81. DOI https://doi.org/10.17581/ bp.2018.07206

DRAPER, I., L HEDENÄS \& G.W. GRIMM. 2007. Molecular and morphological incongruence in European species of Isothecium (Bryophyta) - Molecular Phylogenetics and Evolution 43(3): 700-716. https:// doi.org/10.1016/j.ympev.2006.09.021

DRAPER, I., L. HEDENÄS, M. STECH, J. PATIÑO, O. WERNER, J.M. GONZALEZ-MANCEBO, M. SIM-SIM, T. LOPES \& R.M. ROS. 2015. How many species of Isothecium (Lembophyllaceae, Bryophyta) are there in Macaronesia? A survey using integrative taxonomy. Botanical Journal of the Linnean Society 117(3): 418-438. HTTPS:/ /DOI.ORG/10.1111/BOJ.12250

ENROTH, J., S. OLSSON, S. HUTTUNEN, V. BUCHBENDER, R., TANGNEY, M. STECH, L. HEDENÄS \& D. QUANDT. 2019. Orthostichellaceae fam. nov. and other novelties in pleurocarpous mosses re- 
vealed by phylogenetic analyses. - The Bryologist 122(2) : 219-245.

ENROTH, J., J. SHEVOCK \& M. IGNATOV. 2018. Mawenzhangia thamnobryoides (Bryophyta, Lembophyllaceae), a new moss genus and species from the Shangri-la region of Yunnan Province, China. - Phytotaxa 346(3): 237-246. doi.org/10.11646/phytotaxa.346.3.3

FREY, W. \& M. STECH. 2009. Bryophyta (Musci, mosses). - In: Frey, W. (ed.). Syllabus of plant families A. Engler's Syllabus der Pflanzenfamilien. Part 3. Bryophytes and seedless vascular plants. 13th ed.. Gebr. Borntraeger Verlagsbuchhandlung, Stuttgart, Germany: 116-257.

GARDINER, A., M. IGNATOV, S. HUTTUNEN \& A. TROITSKY. 2005. On resurrection of the families Pseudoleskeaceae Schimp. and Pylaisiaceae Schimp. (Musci, Hypnales). - Taxon 54: 651-663.

GOFFINET, B., W.R. BUCK \& A.J. SHAW. 2009. Morphology, anatomy, and classification of the Bryophyta. - In: Goffinet, B. \& A.J. Shaw (eds.). Bryophyte biology, 2nd edn. Cambridge: Cambridge University Press: 55-138.

GROUT, A.J. 1929. Check list of the pleurocarpous mosses of North America North of Mexico, $32 \mathrm{pp}$.

HALL, T.A. 1999. BioEdit: a user-friendly biological sequence alignment editor and analysis program for Windows 95/98/NT. - Nucleic Acids Symposium Series 41: 95-98.

HEDENÄS, L. 1992. Flora of Madeiran pleurocarpous mosses (Isobryales, Hypnobryales, Hookeriales). - Bryophytorum Bibliotheca 44: 165 pp.

HEDENÄS L. 2017. Scandinavian Oncophorus (Bryopsida, Oncophoraceae): species, cryptic species, and intraspecific variation. - European Journal of Taxonomy 315: 1-34.

HODGETTS, N.G. \& A. VANDERPOORTEN. 2018. Isothecium myosuroides var. brachythecioides (Dixon) Braithw. reinstated as a species, I. interludens Stirt. - Journal of Bryology 40(4), 316-323. DOI: $10.1080 / 03736687.2018 .1514176$

HUTTUNEN, S., N. BELL, V.K. BOBROVA, V. BUCHBENDER, W.R. BUCK, C.J. COX, B. GOFFINET, L. HEDENÄS, B.-C. HO, M.S. IGNATOV, M. KRUG, O.I. KUZNETSOVA, I.A. MILYUTINA, A.E. NEWTON, S. OLSSON, L. POKORNY MONTERO, J. SHAW, M. STECH, A.V. TROITSKY, A. VANDERPOORTEN \& D. QUANDT. 2012. Disentangling knots of rapid evolution: origin and diversification of the moss order Hypnales. - Journal of Bryology 34(3): 187-211.

IGNATOV, M.S. 1999. Bryophyte flora of the Huon Peninsula, Papua New Guinea. LXIII. On the pseudoparaphyllia in Brachytheciaceae and Meteoriaceae (Musci). - Acta Botanica Fennica 165: 73-83.

IGNATOV, M.S., O.M. AFONINA, E.A. IGNATOVA et al. 2006. Checklist of mosses of East Europe and North Asia. - Arctoa 15: 1-130.

IGNATOV, M.S., A.V. FEDOROVA \& V.E. FEDOSOV. 2019. On the taxonomy of Anomodontaceae and Heterocladium (Bryophyta). - Arctoa 28(1): 75-102.

IGNATOV, M.S. \& S. HUTTUNEN. 2002. Brachytheciaceae (Bryophyta) - a family of sibling genera. - Arctoa 11: 245-296.

KATOH, K. \& D.N. STANDLEY. 2013. MAFFT Multiple Sequence Alignment Software Version 7: Improvements in Performance and Usability. - Molecular Biology and Evolution 30(4): 772-780.

KUČERA, J., O.I. KUZNETSOVA, A. MANUKJANOVÁ \& M.S. IGNATOV. 2019. A phylogenetic revision of the genus Hypnum: Towards completion. - Taxon DOI: 10.1002/tax.12095
MILLER, M.A., W. PFEIFFER \& T. SCHWARTZ. 2010. Creating the CIPRES Science Gateway for inference of large phylogenetic trees. In: Proceedings of the Gateway Computing Environments Workshop (GCE), 14 Nov. 2010, New Orleans, LA: 1-8.

MÜLLER, K. 2005. SeqState. - Applied Bioinformatics 4 (1): 65-69.

NOGUCHI, A. \& Z. IWATSUKI. 1989. Illustrated Moss Flora of Japan, Vol. 3. - Hattori Botanical Laboratory, Nichinan: 492-742.

NOGUCHI, A.,Z. IWATSUKI \& T. YAMAGUCHI. 1991. llustrated Moss Flora of Japan, Vol. 4. - Hattori Botanical Laboratory, Nichinan: 743 1012.

NORRIS, D.H. 2014. Bryolawtonia. - In: Flora of North America North of Mexico. Vol. 28, Oxford University Press, New York: 611-613.

OLSSON, S., V. BUCHBENDER, J. ENROTH, S. HUTTUNEN, L. HEDENÄS \& D. QUANDT. 2009. Evolution of the Neckeraceae: resolving the backbone phylogeny. - Systematics and Biodiversity 7 419-432. https://doi.org/10.1017/S1477200009990132

QUANDT, D., S. HUTTUNEN, R. TANGNEY \& M. STECH. 2009. Back to the future? Molecules take us back to the 1925 Classification of the Lembophyllaceae (Bryopsida). - Systematic Botany 34(3): 443 454.

QUANDT, D., R.S. TANGNEY, J.-P. FRAHM \& W. FREY. 2000. A molecular contribution for understanding the Lembophyllaceae (Bryopsida) Based on noncoding chloroplast regions (cpDNA) and ITS2 (nrDNA) sequence data. - Journal of the Hattori Botanical Laboratory 89: 71-92.

RAMBAUT, A., \& A.J. DRUMMOND. 2007. Tracer. - Computer program and documentation distributed by the author, website http:// beast. bio. ed. ac. uk/Tracer

RONQUIST, F., M. TESLENKO, P. VAN DER MARK, D.L. AYRES, A. DARLING, S. HÖHNA, B. LARGET, L. LIU, M.A. SUCHARD \& J.P. HUELSENBECK. 2012. MrBayes 3.2: efficient Bayesian phylogenetic inference and model choice across a large model space. - Systematic Biology 61: 539-542.

SIMMONS, M.P. \& H. OCHOTERENA. 2000. Gaps as characters in sequence-based phylogenetic analyses. - Systematic Biology 49(2): 369-381

SPIRINA, U.N. \& M.S. IGNATOV. 2015. Bilobed leaves in mosses? Structure and adaptive significance of proximal branch leaves in Lembophyllaceae. - Arctoa 24(1): 124-140.

STAMATAKIS, A. 2014. RAxML Version 8: A tool for phylogenetic analysis and post-analysis of large phylogenies. - Bioinformatics 10.1093/ bioinformatics/btu033

TANGNEY, R.S. 1997. A generic revision of the Lembophyllaceae. Journal of the Hattori Botanical Laboratory 81: 123-153.

TROITSKY, A.V., M.S. IGNATOV, V.K. BOBROVA \& I.A. MILYUTINA. 2008. Contribution of genosystematics to current concepts of phylogeny and classification of Bryophytes. - Biochemistry (Moscow) 72(12): 1368-1376.

VANDERPOORTEN, A., L. HEDENÄS, C.J. COX \& A.J. SHAW. 2002. Phylogeny and morphological evolution of the Amblystegiaceae (Bryopsida). - Molecular Phylogenetics and Evolution 23 (1): 1-21.

WANG, J.-J. \& Y. JIA. 2019. Reappraisal of Taxiphyllum arcuatum (Bosch \& Sande Lac.) S. He based on molecular and morphological data. The Bryologist 122(4): 559-567.

Appendix 1. Specimens and accession number used in concatenated analysis.

Species

Bryolawtonia vancouveriensis

Camptochaete arbuscula

Camptochaete arbuscula var. tumida

Camptochaete deflexa

Dolichomitra cymbifolia 1

Dolichomitra cymbifolia 2 isolate and specimen for new sequences

B222

s.n.

SH10

s.n.

s.n.

Deguchi HIRO 79

$\begin{array}{lll}\text { ITS } & \text { trnG } & \operatorname{trnSF}(* \text {-trnLF }) \\ \text { FM161082 } & - & \text { AM990349 } \\ \text { AF403629 } & - & - \\ \text { FM161087 } & - & \text { AM990353 } \\ \text { AF188057 } & - & - \\ \text { AF509855 } & - & - \\ \text { LS999115 } & \text { AY908344 } & \text { LR130214 } \\ & & \text { \& AF509558 }\end{array}$


Species

Dolichomitra cymbifolia 3

Dolichomitra cymbifolia 4

Dolichomitriadelphus hakkodensis 2 OK2396 Kunashir, Ignatov 06-1125, MHA

Dolichomitriopsis cherdantsevae 1 OK2371 Primorsky, Ignatov \& Ignatova

Dolichomitriopsis cherdantsevae 2 Dolichomitriopsis crenulatus

Dolichomitriopsis diversiformis 1

Dolichomitriopsis diversiformis 2

Dolichomitriopsis diversiformis 3 (as D. subdiverisormis)

Dolichomitriopsis diversiformis 4

Dolichomitriopsis diversiformis 5

Dolichomitriopsis diversiformis 6 Fallaciella gracilis

Fifea aciphylla

Heterocladium heteropterum 1

Heterocladium heteropterum 2

Heterocladium heteropterum 3

Heterocladium wulfsbergi

Homalia trichomanoides 1

Homalia trichomanoides 2

Isotheciastrum subdiversiforme 1

Isotheciastrum subdiversiforme 2

Isothecium algarvicum 1

Isothecium algarvicum 2

Isothecium algarvicum 3

Isothecium algarvicum 4

Isothecium algarvicum 5

Isothecium algarvicum 6

Isothecium algarvicum 7

Isothecium algarvicum 8

Isothecium alopecuroides 1

Isothecium alopecuroides 2

Isothecium alopecuroides 3

Isothecium alopecuroides 4

Isothecium alopecuroides 5

Isothecium alopecuroides 6

Isothecium alopecuroides 7

Isothecium alopecuroides 8

Isothecium alopecuroides 9

Isothecium alopecuroides 10

Isothecium alopecuroides 11

Isothecium alopecuroides 12

Isothecium alopecuroides 13

Lembophyllum clandestinum 1

Lembophyllum clandestinum 2

Lembophyllum divulsum 1

Lembophyllum divulsum 2

Looseria orbiculata 1

Looseria orbiculata 2

Mawenzhangia thamnobryoides

Neckera menziesii

Neckera pennata 1

Neckera pennata 2

Neobarbella comes

Nogopterium gracile 1

Nogopterium gracile 2

Nogopterium gracile 3

Nogopterium gracile 4

Pseudanomodon attenuatus 1

Pseudanomodon attenuatus 2 isolate and specimen for new sequences

OK2125 Shikotan, Bakalin K-45-29-07, MHA

OK2395 Shikotan, Bakalin K-42-4-07, MHA

$$
\text { 06-2397, MW9037075 }
$$

OK2372 Primorsky, Ignatov 07-160, MW9037078 OK2121 Iturup, Bakalin K-16-45-07, MHA9038397 OK2122 Kunashir, Ignatov 06-1847, MHA s.n.

T11

OK2370 Primorsky, Ignatov \& Ignatova 13-1742, MW9037072

OK2123 Primorsky, Ignatov \& Ignatova 13-1742, MW9037072

OK2394 Kunashir, Koroteeva 15-10/4-3, MHA

s.n.

s.n.

B350

OK2224

OK2223

AnomF19

B218

OK2219

OK2369 Japan, Ignatov \& Ignatova 97-580, MHA T57

$\mathrm{T} 52$

T53

IP1

IP2

GO1

PA1

PA3

MD4

$\mathrm{T} 23$

T91

T31

AZ

$\mathrm{T} 25$

T46

T38

T39

$\mathrm{T} 74$

T79

T81

OK2466 Ingushetia, Ignatov et al. 2018, MW 9090725

$\mathrm{T} 12$

SH103

s.n.

B295

s.n.

s.n.

s.n.

sn

B161

NF48

NF50

s.n.

Buchbender 348

Pt gr

s.n.

B408

OK2209

OK2169
ITS

trn $\mathrm{G} \quad \operatorname{trn\mathrm {SF}}(*$-trn $\mathrm{LF})$

MN854444 MN841342 -

MN854442 MN841341 MN841361

MN854443 -

MN854438 MN841339 MN841357

MN854430 MN841331 MN841349

MN854431 MN841332 MN841350

MN854436 MN841337 MN841355

MN854433 MN841334 MN841352

FM161098 -

DQ294917 DQ294781 -

MN854432 MN841333 MN841351

MN854434 MN841335 MN841353

MN854435 MN841336 MN841354

AF188058

AF295041 - _ -

FM161116 - $\quad$ AM990377

MN030527 - $\quad$ MN045120

MN030526 - MN045119

MN030542 - MN045121

FM161126 - AM990385

MN030524 - -

MN854437 MN841338 MN841356

DQ294918 DQ294827 -

DQ294867 DQ294822 -

DQ294868 DQ294823 -

HQ380897 HQ380953 HQ381007*

HQ380898 HQ380954 HQ381008*

HQ380904 HQ380959 HQ381014*

HQ380906 HQ380961 HQ381016*

HQ380908 HQ380963 HQ381017*

HQ380914 -

DQ294879 DQ294793 -

DQ294889 DQ294851 -

DQ294915 DQ294801 -

HQ380916 HQ380971 HQ381034*

DQ294881 DQ294795 -

DQ294895 DQ294816 -

DQ294903 DQ294808 -

DQ294907 DQ294809 -

DQ294909 DQ294840 -

DQ294910 -

DQ294911 -

MN854426 MN841327 MN841345

DQ294916 DQ294782 -

FM161145 - $\quad$ AM990401

AF403630

FM161146 -

FM1611461

AY009807 -

AJ862691 - -

AF509860 -

MG515239 - _ -

FM161167 - $\quad$ FM210305

MN854440 - $\quad$ MN841359

MN854441 - $\quad$ MN841360

AF395628 -

HE660012 - HE717062*

HQ268249 - -

KC249957 - -

LS999114 - $\quad$ LR130213

MN030519 - $\quad$ MN045086

MN030517 - - 
Species

Pseudanomodon giraldii Pseudisothecium cardotii 1 Pseudisothecium cardotii 2 Pseudisothecium cristatum 1 Pseudisothecium cristatum 2 Pseudisothecium cristatum 3

Pseudisothecium cristatum 4

Pseudisothecium holtii

Pseudisothecium interludens 1

Pseudisothecium interludens 2

Pseudisothecium interludens 3

Pseudisothecium interludens 4

Pseudisothecium interludens 5

Pseudisothecium interludens 6

Pseudisothecium interludens 7

Pseudisothecium myosuroides 1

Pseudisothecium myosuroides 2

Pseudisothecium myosuroides 3

Pseudisothecium myosuroides 4

Pseudisothecium myosuroides 5

Pseudisothecium myosuroides 6

Pseudisothecium myosuroides 7

Pseudisothecium myosuroides 8

Pseudisothecium myosuroides 9

Pseudisothecium myosuroides 10

Pseudisothecium myosuroides 11

Pseudisothecium myosuroides 12

Pseudisothecium prolixum 1

Pseudisothecium prolixum 2

Pseudisothecium prolixum 3

Pseudisothecium prolixum 4

Pseudisothecium prolixum 5

Pseudisothecium prolixum 6

Pseudisothecium prolixum 7

Pseudisothecium prolixum 8

Pseudisothecium prolixum 9

Pseudisothecium prolixum 10

Pseudisothecium prolixum 11

Pseudisothecium prolixum 12

Pseudisothecium stoloniferum 2

Pseudisothecium stoloniferum 3

Pseudisothecium stoliniferum 1

Rigodium implexum 1

Rigodium implexum 2

Rigodium pseudothuidium 2

Rigodium pseudothuidium 1

Rigodium toxarion

Thamnobryum ellipticum

Thamnobryum negrosense

Touwia laticostata

Tripterocladium leucocladulum 1 Tripterocladium leucocladulum 2

Weymouthia billardieri

Weymouthia cochlearifolia 1

Weymouthia cochlearifolia 2

Weymouthia mollis 1

Weymouthia mollis 3

Weymouthia mollis 2 isolate and specimen for new sequences

Jiangxi3

OK2472 California, Shevock 51319, MW9112752

CAN

USA

OK2469 California, Shevock 53668, MW9112676

OK2470 California, Shevock 48391, MW9075665

T54

T65

T67

$\mathrm{T} 72$

Hodgetts_6780

Hodgetts_9099

T66

GBR2

Hodgetts_9099

T60

T59

GO2

$\mathrm{GO} 3$

Kucera_15467

TE1

CAN1

AZ

MD

OK2468 Norway Ignatov \& Ignatova 06-5024, MW 9046192

T51

MD1

s.n.

Cafofo 242201

MD7

s.n.

s.n.

s.n.

s.n.

s.n.

MD8

s.n.

s.n.

T56

OK2471 California, Shevock 53640, MW9112640

OK2473 Oregon, 22 Aug 1989 Ignatov s.n., MW9046232 Ri29

s.n.

B559

s.n.

s.n.

B546

B420

B261

SH431

s.n.

s.n.

SZ

s.n.

DQ

s.n.

s.n.
ITS trnG trnSF(*-trnLF)

KF770680 - KF770518

MN854439 MN841340 MN841358

HQ380917 HQ380972 HQ381038*

HQ380918 HQ380973 HQ381040*

MN854424 MN841325 MN841343

MN854425 MN841326 MN841344

DQ294919 -

DQ294923 DQ294834 -

DQ294926 DQ294836 -

DQ294925 DQ294838 -

MH465612 -

MH465613 - _

DQ294921 DQ294835 -

HQ380928 HQ380982 HQ381055*

MH465613 -

DQ294927 DQ294830 -

DQ294924 DQ294829 -

HQ380921 HQ380975 HQ381044*

HQ380922 HQ380976 HQ381045*

MK327347 -

HQ380923 HQ380977 HQ381046*

HQ380919 -

HQ380925 HQ380979 HQ381050*

HQ380926 HQ380980 HQ381051*

AY737479 -

MN854427 MN841328 MN841346

DQ294922 DQ294821 -

HQ380934 HQ380989 HQ381062*

KF648790 -

KM676255 -

HQ380940 HQ380994 HQ381068*

KM676258 - -

KM676256 - -

EU477598 - -

KF648791 - -

KM676261 - _ -

HQ380941 HQ380995 HQ381069*

KF64880 - -

KM676257 - -

DQ294920 DQ294826 -

MN854428 MN841329 MN841347

N854429 MN841330 MN841348

FM161209 AM990436 -

AF543551 -

FM161210 - $\quad$ AM990437

AF509842 -

AF509843 -

FM161220 - $\quad$ FM210325

FM161225 - $\quad$ FM210327

FM161233 - $\quad$ FM882221 \&

FM210330

FM161235 - $\quad$ AM990450

AY188175 - _ -

AF188053 - -

FM161236 AM990451 -

AJ862693 -

FM161237 - $\quad$ AM990452

HQ380917 - _ -

AJ862694 - 